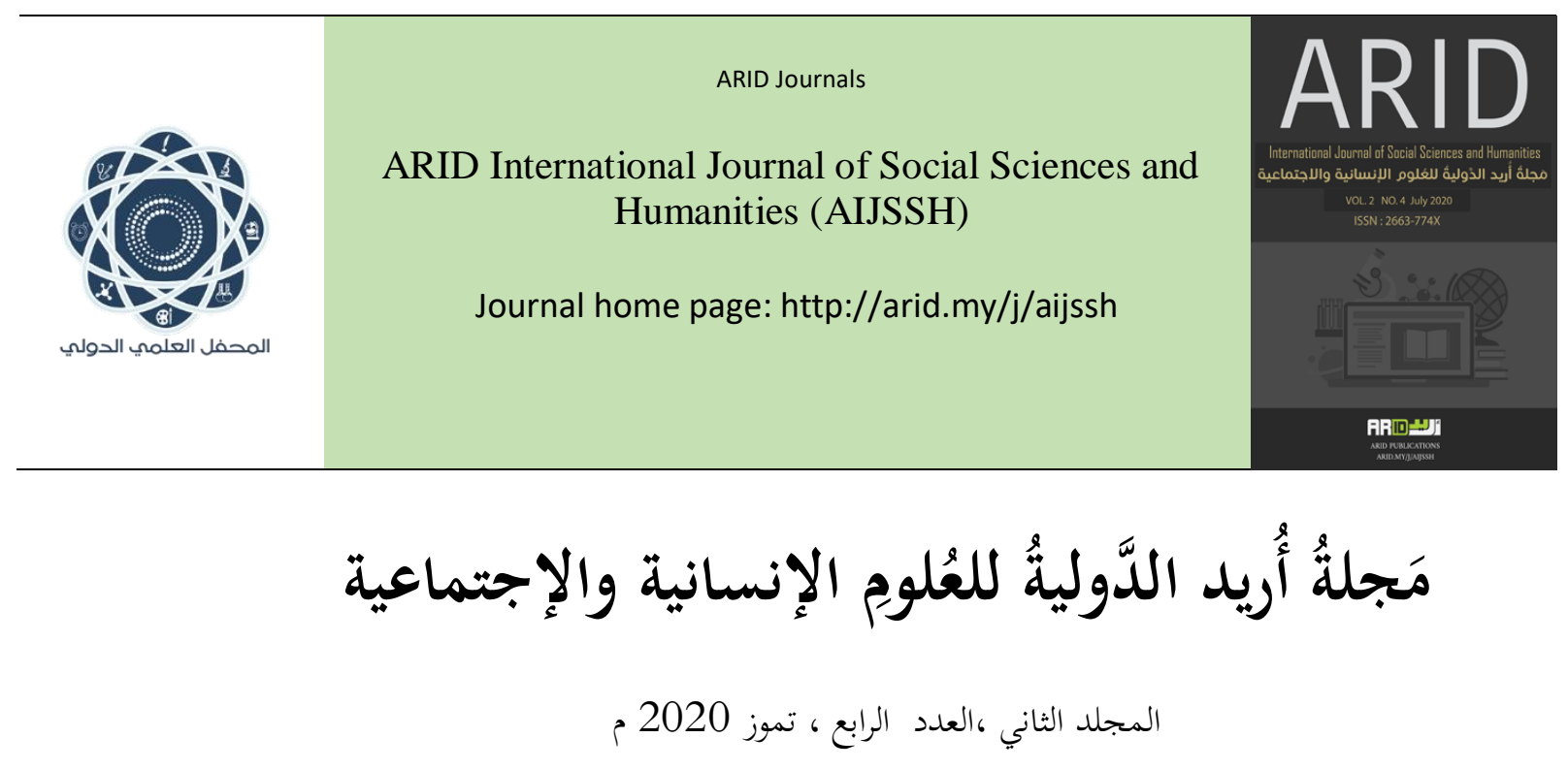

Concealment of the secret in the struggle and weevil self in the light of the

\title{
Holy Quran
}

Prof. Dr. Dhuha Adil Mahmood*

Mas. Mona Adel Mahmoud

College of education for women-University of Baghdad- Iraq

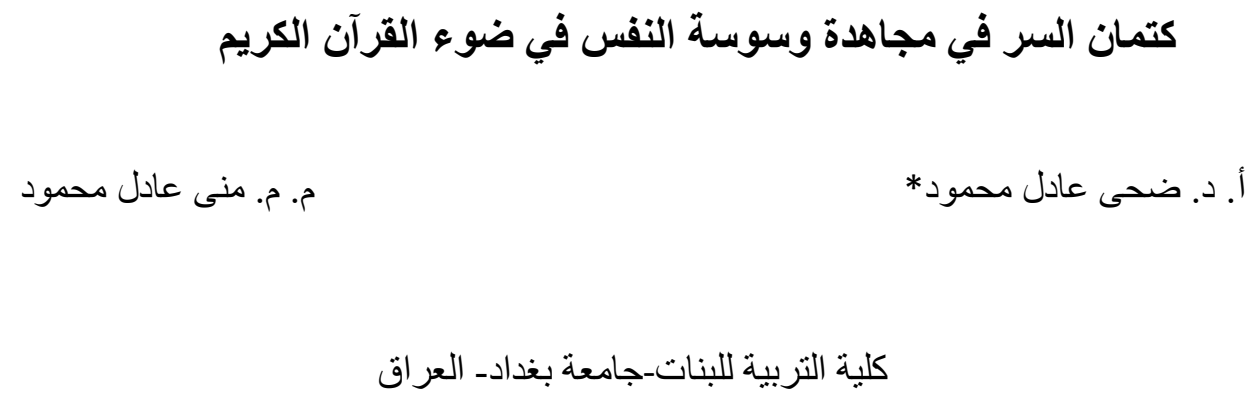

hh.uu10@yahoo.com

arid.my/0004-0331

https://doi.org/10.36772/arid.aijssh.2020.2412 


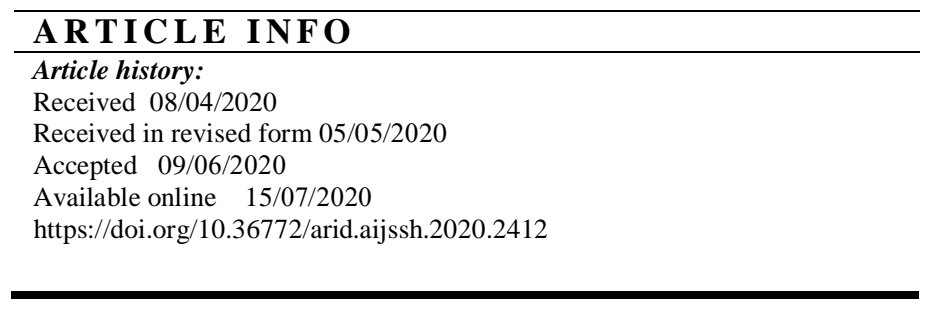

\begin{abstract}
Praise be to Allah. Prayers and peace be upon the Messenger of Allah. After that, the reason for choosing this subject from the Islamic point of view is that there is a fear among many people of the state of whispers within the human psyche, which they believe comes from Satan only. After we applied two scientific approaches, namely the inductive and analytical approaches to the texts of the verses of the Koran and their interpretation shows that the whisper of the soul is before divulging the secret and does not know the devil as long as the servant mute his secret, either after divulging the secret and the whispers of the devil. The whispers of the soul is not held accountable by God and even angels do not write the whispers only after pronounced or written by the Muslim slave and the biggest example of this is in the fatwa of divorce does not occur divorce only after uttered or written. It is called self - jihad great Jihad mentioned that ( Ibn 'Uthaymeen )in the fatwa of self - struggle, and that the devil does not know what leaked the same human rights and what they hide. The credibility of the verse in Sura 14: "When the jinn found out that if they knew the unseen they would not have been in humiliating torment." Therefore, Allah the Almighty stated in Surah An-Nyssa '(verse 76): "The devil's kid was weak." If a Muslim slave knows that Satan does not know the unseen until after revealing the mystery, this is the weak point of Satan and the power of the believer.
\end{abstract}

Keywords: Struggling and obsessing oneself, keeping a secret, the Noble Qur'an. 


\section{الملخص}

الحمـد للـه و الصـلاة والسـلام على رسـول اللـه و أمـا بعـد: فـإن سبب اختبارنـا لهذا الموضـوع مـن الناحيـة الإسـلامية هـو

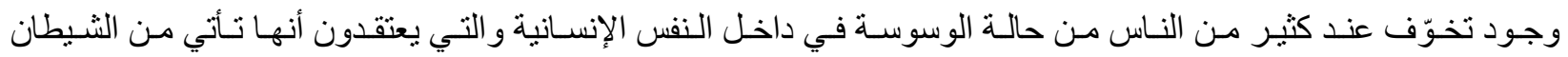

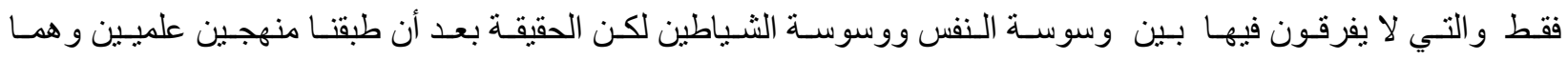

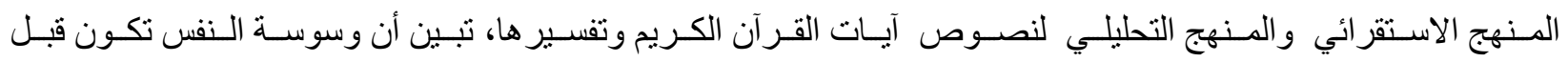

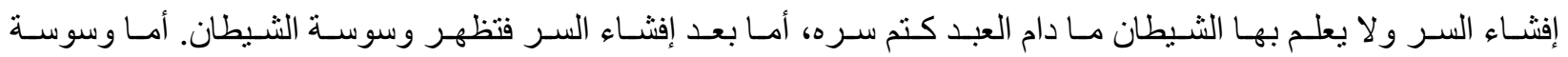
الـفس فـلا يحاسـب اللـه عليهـا فالملائكـة لا تكتب الوسوسـة إلا بعـد أن يلفظهـا أو يكتبهـا العبـد المسلم وأكبر مثنال على ذللك هو في فتوى الطلاق فلا يقع الطلاق إلا بعد أن يتلفظ به أو يكتبه. إذ تسمى مجاهدة النفس الجهاد الأكبر

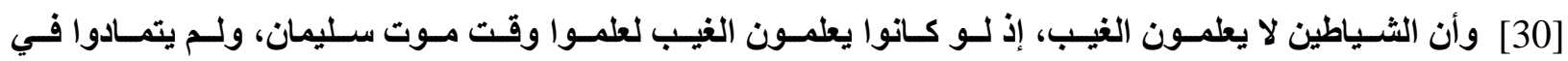

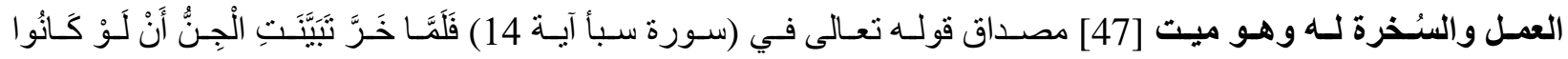

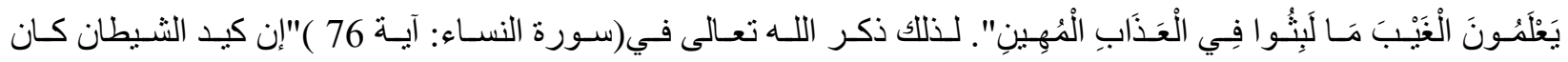

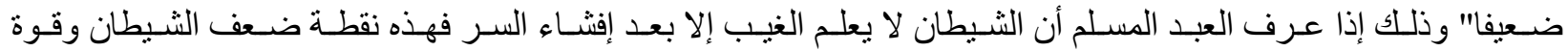
المؤمن الذي ليس للشيطان على المؤمن سلطانا. 


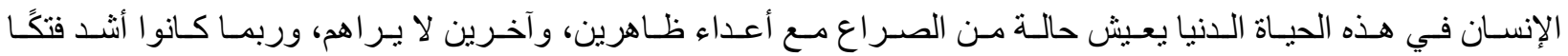

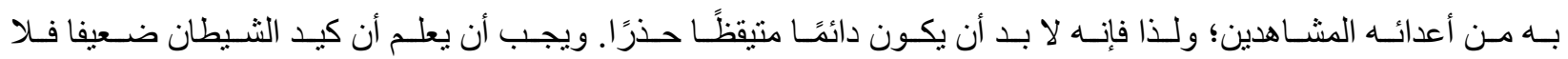

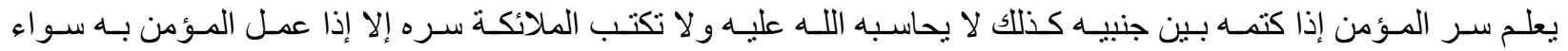
بـاللفظ أو بالكتابـة. وقـال أبـو بكر الصـديق في وصـيته لعمـر رضــي اللـه عنهــا" [8] إن أول مـا احـرك نفسـك التـي بـين

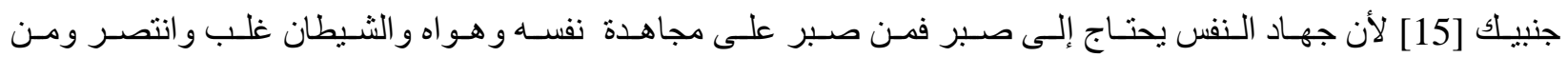
جـزع و أفثـى سـره علمـت شـياطين الإنس و الجـن سـره وغلبته فأصـبح عبـدا ذلبلا في يـدي شـيطانه وهـواه. و إن أعدى أعداء المـرء نفسـه التـي بـين جنبيـه فإنهـا تحثـه على نيـل كل مطلـوب والفوز بكل لـذة حتى وإن خالفت أمسر اللـه وأمـر

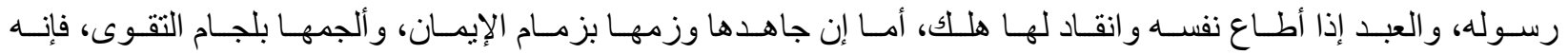
يحرز بـذلك نصـرًا في ميـدان مـن أعظـم ميـادين الجهـاد. قـال رسـول اللـه r: "ألا أخبـركم بـالمؤمن؟ مـن أمنـهـ النـاس على

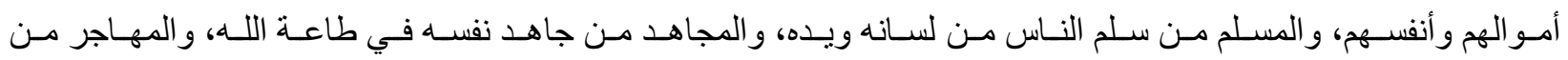
هجر الخطايـا والـنوب". [33] فجهـاد الـفس إذاً مـن أفضـل أنـواع الجهـاد، "جهـاد المـرء نفسـهـهـ هـو الجهـاد الأكمـل، قـال

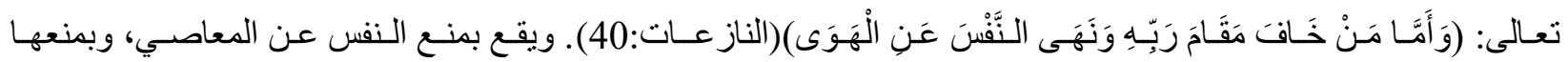
من الثبهات، وبمنعها من الإكثار من الثهوات المباحة لتتوفر لها في الآخرة". [27] أولا: مبـررات الدراسـة: مـن الأسـباب التـي دعـت لدراسـة هـذا الموضـوع هـو وجـود تخـوف عنـــــــــر مـن النـاس مـن حالـة الوسوسـة في داخـل الـفس الإنسـانية و التـي يعتقدون أنهـا مـن الشـيطان لكن الحقيقـة أن وسوسـة الـفس لا يعلـم بهـا الشيطان لذلك لا يحاسب العبد على وسوسة النفس إلا بعد أن يلفظها أو يكتبها. ثانيا: مشكلة الدراسة: يجيب هذا البحث عن جملة من الإشكاليات أهمها: - ماذا تسمى مجاهدة النفس هل الجهاد الأصغر أم الأكبر؟ - ل يعلم الثبطان ما تسر نفس الإنسان البشرية أم لا؟ - هل تحاسب النفس الإنسانية عما في داخلها قبل أن تتلفظ به أو تكتبه؟ 


\section{ثالثا: أهمية البحث: تتلخص أهمية البحث في النقاط التالية:}

إن كتم الأسـر ار شـيء فطـري ترشـــ إليـهـ الطبيعـة البشـرية .. و هـو خاصـية إنسـانية في العلاقـات الاجتماعيـة مـن حيـث

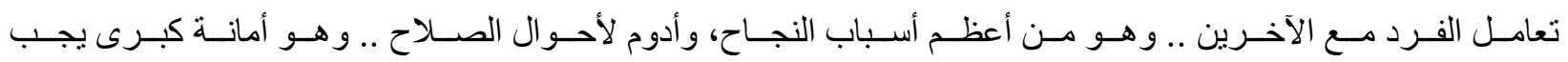

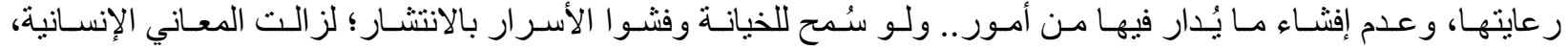

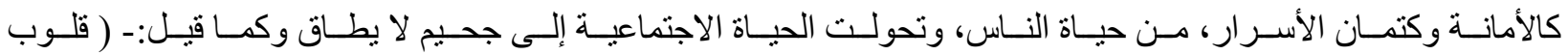

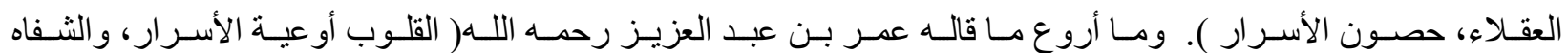
أقفالها، و الألسن مفاتيحها، فليحفظ كلٌ امرئ مفتاح سرّه ). [49]

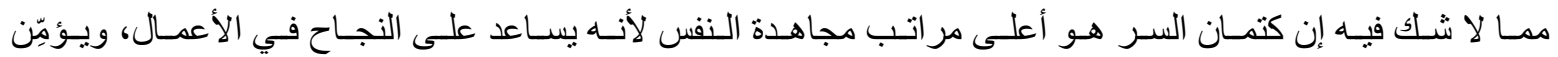
السـالك مـن أخطـار الطريـق، ويـريح الضــير، ويحفظ للإنسـان مكاسـب طيبـة مـا دامـت بعيـدة عـن علـم الغيـر، ولا يتيح

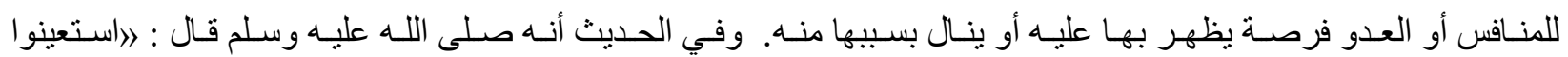

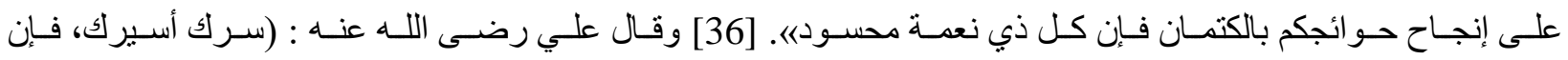
تكلمـت بـه صـرت أسـيره) ـ وقـال بعض الأدبـاء: (مسن كتم سـره كـان الخيـار بيده، ومـن أفثــاه كـان الخيـار عليـه). [48]

\section{رابعا: أهداف البحث: يهرف البحث الحالي إلى:}

- - بيان مفهوم مجاهدة النفس ومفهوم كتمان السر في القرآن الكريم. - بيان العلاقة بين مجاهدة النفس وكتمان السر حسب قصص القرآن الكريم. - بيان حقيقة كيد الثيطان الضعيف في عدم معرفته الغيب ومكنونات النفس البشرية. - بيان صدق فتوى الطلاق في عدم وقوعها إذا كتم العبد ذلك في داخله ما لم يتلفظ به أو يكتبه. - - بيان دور كتمان السر في النصر على الأعداء.

خامسـا: حـود البحـث: تقتصـر الدراسـة الحاليـة على الحقبـة الزمنيـة منـــنـزول القـرآن والأحاديـث النبويـة إلىى

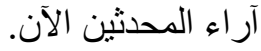




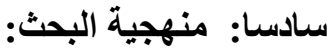

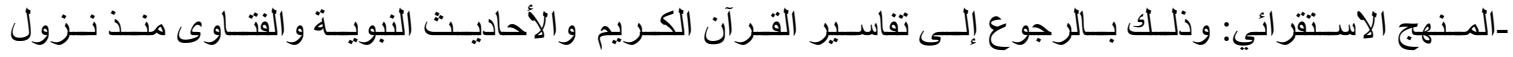
القرآن إلى عصرنا الحاضر.

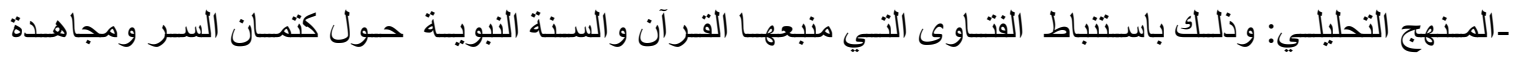
النفس و الوسوسة و الربط بينها، و استنتاج أهم النتائج المتعلقة بها. سـابعا: دراسـات سـابقة: بعـد البحـث في الأبحـاث العلميـة والأطـاريح الجامعيـة وجـدت دراسـتين لهـا علاقـة بموضوع بحثنا هذا و هي: 1-دراســة: " إفثـــاء السـر فـي الثــريعة الإسـلامية "[5] هـدف البحـث تعـرف مـن يحمـل السـر يكـون سـرهو وعلانيـة

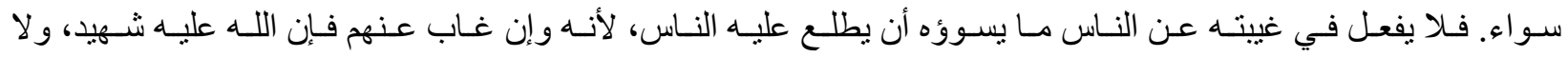

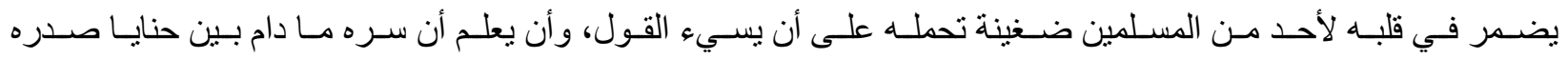

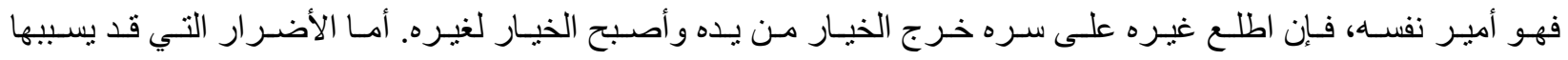

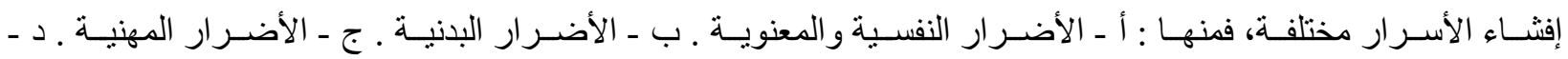
الأضرار المالية.

2ـدراسـة " "حكم إفثـاء السـر في الإسـلام"[57] هـدف البحـث تعـرف شـروط المسـتور عليـه : هذا وقـد اشـترط الإمسام النـووي أن يكـون المسـتور عليـهـ مدـن لـيس معروفـا بـالأذى والفسـاد فأمسا المعـروف بـالأذى والفسـاد فيسـتحب ألا يسـتر عليـه؛ لأن السـتر عليـه يطمعـه في الإيـذاء و الفسـاد وانتهـاك الحرمـات وجسـارة غيـره على مثنل فعلـه و إنمـا يرفـع أمـره

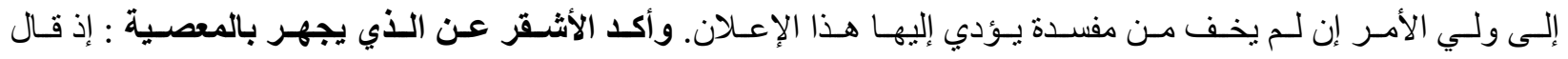
الكمـال بـن الهمـام فـي فتحح القـدير : إذا وصـل الحسال إلـى إثـاعة المعصـية والتهنـك بهـا بـل بعضـهم ربمـا افتخـر بالـذنب

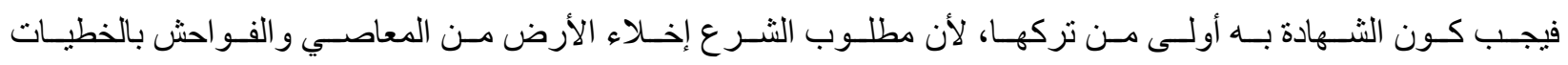

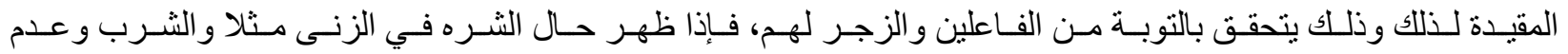
المبـالاة بـهـ وإثـاعته، فيجب تحقيق السبب الآخـر للإخـلاء وهـو الحـدود بخـلاف مـن زنسى مـرة أو مـر ارا مسـتنر ا متخوفـا

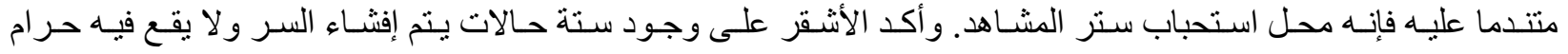

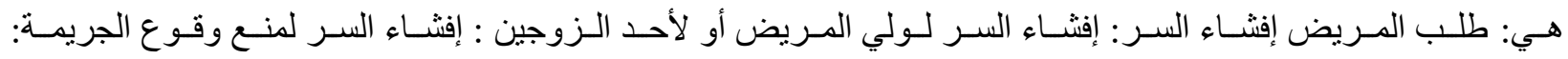
الحالات التي يكون الطبيب فيها حكما: ما فيه حفظ للأمة ووقاية لها: الكثف عن جريمة وقعت . 
ثامنا: خطة البحث: تم تقسيم البحث إلى مقدمة وتمييد وثلاثة مباحث وخاتمة. وتفصيل ذلك: المبحث التمهيدي: مجاهدة وسوسة النفس (لغة واصطلاحا)، كتمان السر (لغة واصطلاحا).

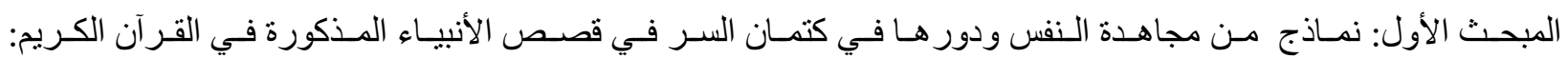
سورة يوسف آية 5، سورة مريم آية 26، سورة القصص آية 10-13، سورة سبأ آية 14. المطلب الأول: مجاهدة النفس ودور ها في كتمان السر في: سورة يوسف آية 5. المطلب الثناني: مجاهدة النفس ودور ها في كتمان السر في سورة مريم آية 26. المطلب الثالث: مجاهدة النفس ودور ها في كتمان السر في سورة القصص آية 10-13. المطلب الر ابع: مجاهدة النفس ودور ها في كتمان السر سورة سبأ آية 14. المبحـث النثاني: نمـاذج مـن مجاهـدة الـنفس ودور هـا في كتمـان السـر في بعض سـور القـرآن الكـريم: سـورة طــه آيـة 7، سورة فصلت آية34، سورة الحجرات آية 12، سورة ق آية 16-18. المطلب الأول: مجاهدة النفس ودور ها في كتمان السر في: سورة طه آية7. المطلب الثاني: مجاهدة النفس ودور ها في كتمان السر في سورة سورة فصلت آية34 المطلب الثالث: مجاهدة النفس ودور ها في كتمان السر في، سورة الحجرات آية 12 المطلب الرابع: مجاهدة النفس ودور ها في كتمان السر سورة ق آية 16-18. المبحث الثالث: نماذج من مجاهدة النفس ودور ها في كتمان السر في فتوى الطلاق. المطلب الأول: نموذج من مجاهدة النفس ودور ها في كتمان السر في فتوى الطلاق. 
تاسعا: الخاتمة: - أهم النتائج - أهم التوصيات

\section{المبحث التمهيدى: مجاهدة وسوسة النفس (لغة واصطلاحا)، كتمان السر (لغة واصطلاحا).}

$$
\text { أولاً: مجاهدة النفس لغة واصطلاحا: }
$$

" قـال ابـن منظـور فـي لسـان العـرب المجاهـدة مصـدر جاهــ يجاهـــ جهـاداً ومجاهـدة وهـو مـأخوذ مـن مـادة "ج هـ د" التـي تـدل علـي المشـقة. ويقـال المجهود هـو اللـبن الذذي أخـرج زبـده لأنـه لايخـرج إلا بتعـب ومشـقة. ولـذا لايقـال اجتهـ

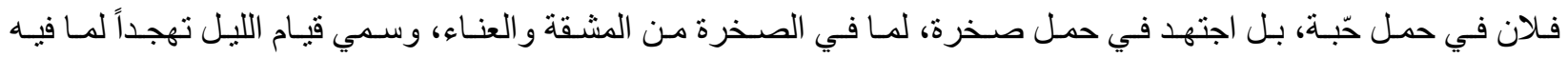

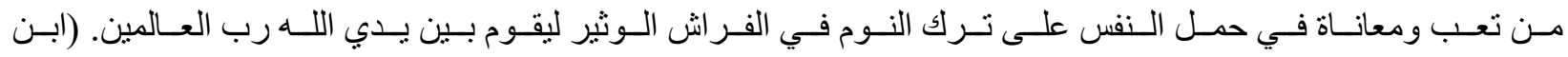
منظور كد.ت: حرف الجيم).

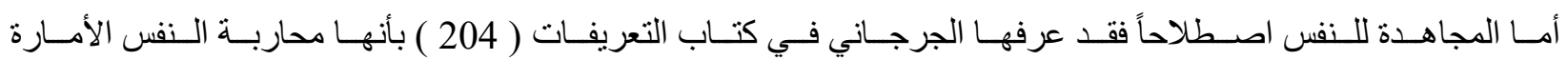

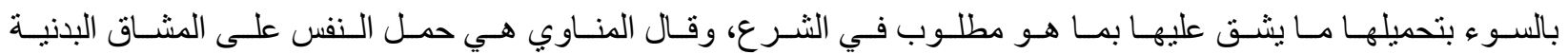
ومخالفة الهوى، وقيل هي بذل المستطاع في أمر المطاع وهو الله عز وجل. [12]

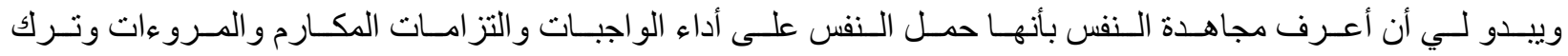
المحرمات و الترفع عن السفاسف و المكرو هات.

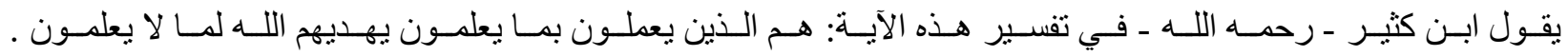

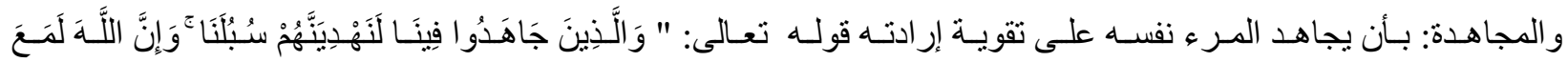

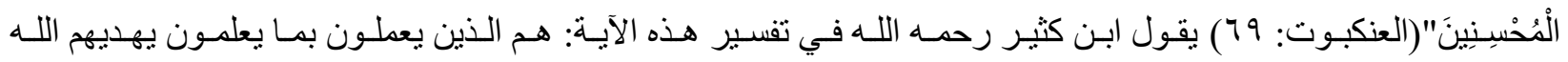

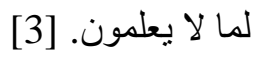

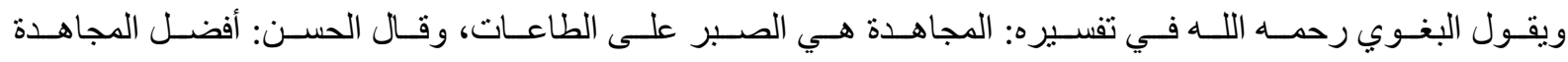

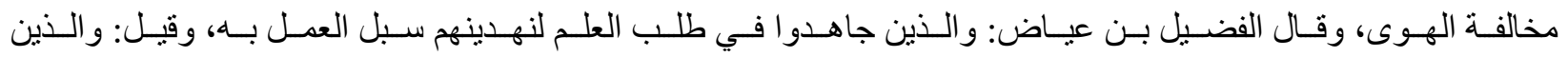




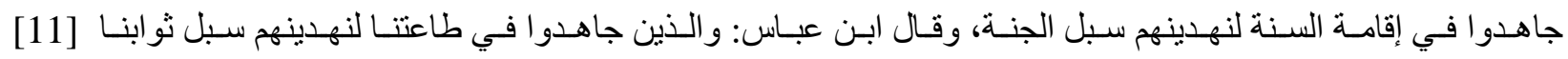
ويقول الثـنقيطي رحمـه اللـه في تفسـبره: إن اللـه أقسـم علـى ذللك بـدليل الـلام في قولـه: لنهـينهم [32] ويقول د. محمــ الأشـقر في تفسيره: هـم الذذين جاهـدوا أنفسـهم في الـدعوة إلى اللـه لطلب مرضـاته. [19] وللجهـاد أربـع مراتب: جهـاد

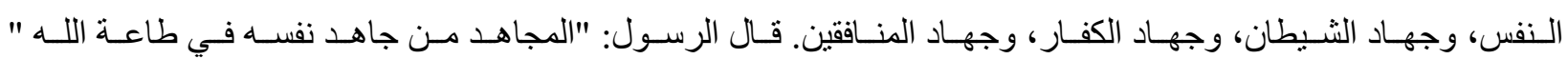
ص ـ أن يجاهدها على تعلم الهذى. الخاطر لابن الجوزي،[57] فجهاد النفس أربع مراتب أيضا: Y- أن يجاهدها على العمل به بعد علمه. بـ أن يجاهدها على الدعوة إليه.

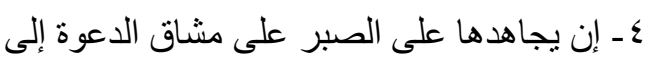
كما قال الرسول صلى الله عليه وسلم"حفت الجنة بالمكاره "

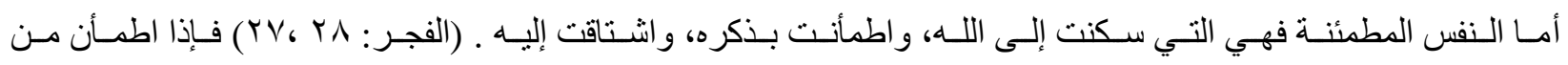

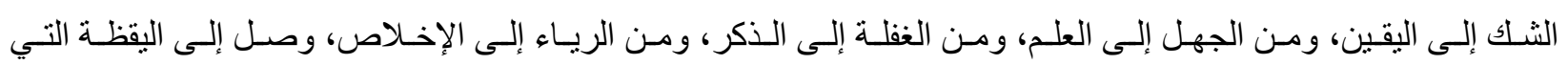

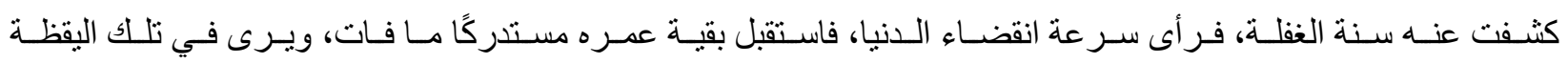
عيوب نفسه، وعزة وقته، و هي أول منازل النفس المطمئنة التي ينشأ منها سفر ها إلى الله والدار الآخرة. [20] ثانيا :كتمان السر لغة واصطلاحاً: الكتمان لغةً: الكتمان مصدر كتم، من باب نصر، يقال: كتم الثيء كَتمًا وكِتمانًا: ستره وأخفاه. [21] الكتمان اصطلاحًا:

الكتمان هو: ستر الحديث ، [7] وقيل: (هو ضبط النفس ضد دوافع التعبير عما يختلج فيها). [6] و السر لغة اسم لما يُسر به الإنسان أي: يكتمه، و أصل الكلمة يدل على إخفاء الثيء وعدم إظهاره. [51] 


$$
\text { فالإسرار خلاف الإعلان[22]قال تعالى: "يعلم ما يسرون وما يعلنون" (البقرة:77). }
$$

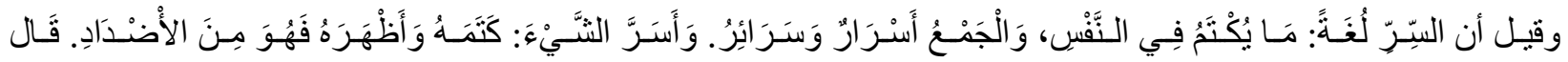

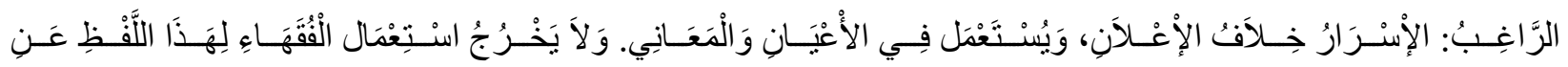
الَْعْنَى اللُغَوِيِّ.

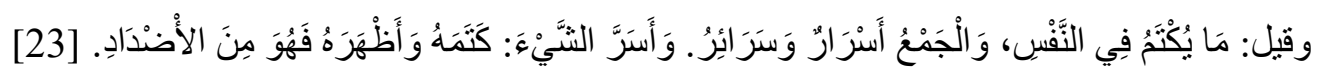

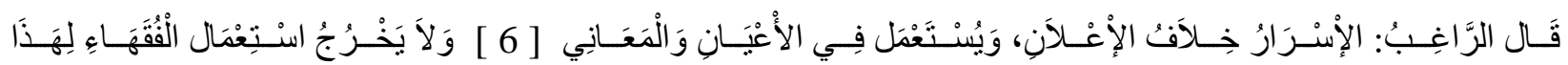

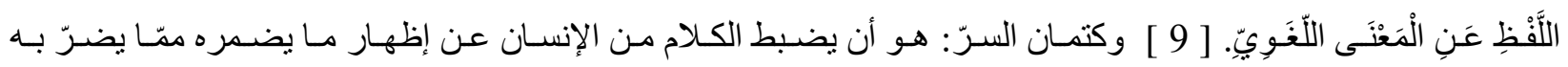
إظهاره و إبداؤه .

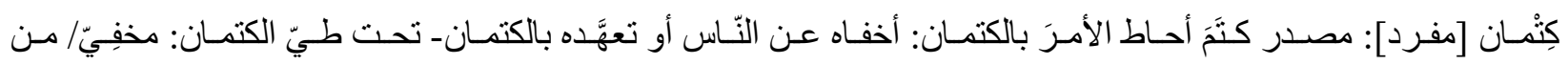
دفائن الغيب وخباياهـ- في طيّ الكتمان: سِرِيّ [42] [18]: والسرّ ينقسم إلى أربعة أنواع

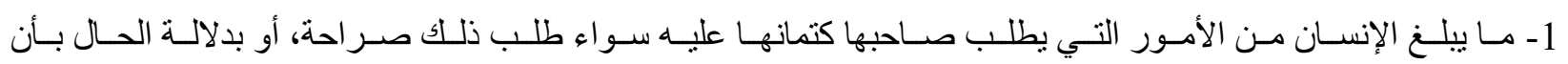
يتعدد الحديث عنها حال الإنفر اد مثناً. 2- ما يريد الإنسان عمله مما تدعو المصلحة إلى كتمانه. 3- ما أمر الثرع بكتمانه وعدم إذاعته. 4- ما كن الأصل إخفاءه و اطلع عليه شخص بسبب مهنته. وموضع ما يعنينا في هذا المقام هو الرابع منها أصالة، وبقية الأنواع معنيّة تبعاً.

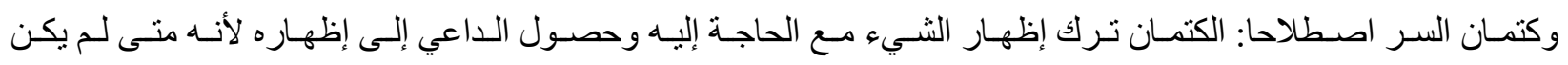
كذللك لا يعد كتماناً . و على هذا الوجه يمدح من يقدر على كتمان السر لأن الكتمان مما يشق على النفس. [56] 


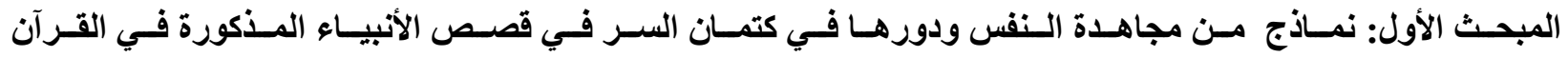
الكريم: سورة يوسف آية 5، سورة مريم آية 26، سورة القصص آية 10-10، سورة سبأ آية 14.

المطلب الأول: مجاهدة النفس ودورها في كتمان السر في:سورة يوسف آية 5.

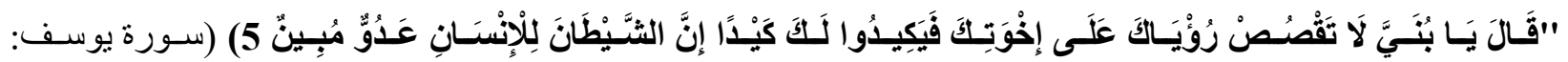

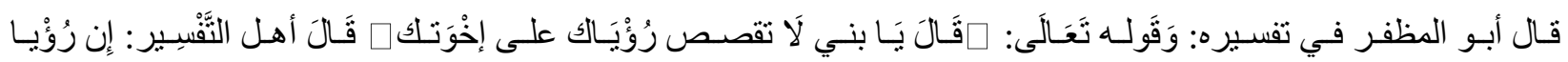

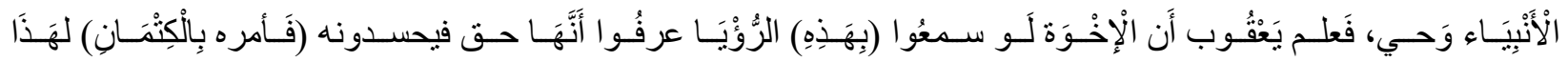

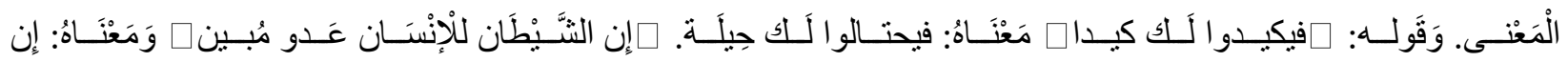

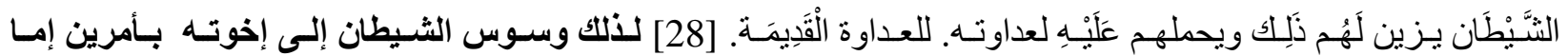

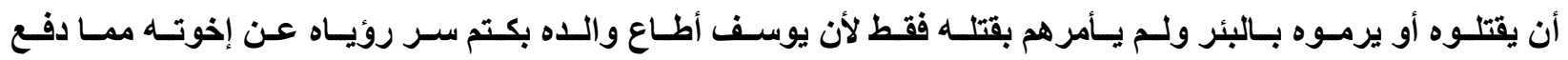
الضـرر عن نفسـه بمجاهدة نفسـه بالجهاد الأكبر وهـو كتم سـره. ومعنسى ذلك إذا رأى الإنسـان في منامـه مـا بسـره ،

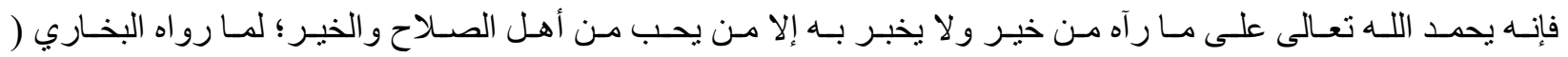

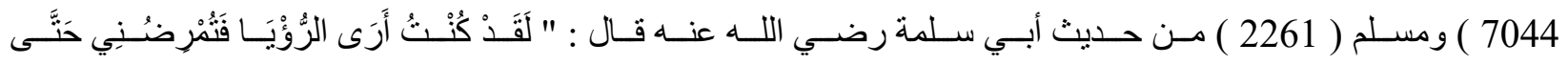

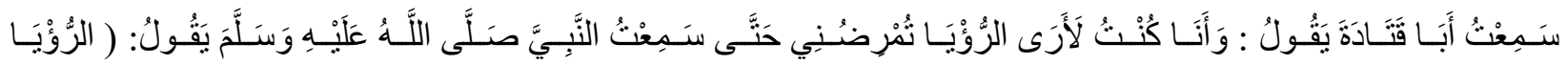

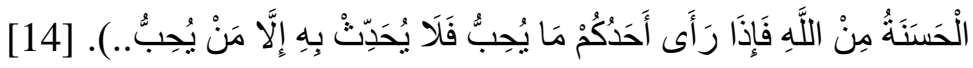

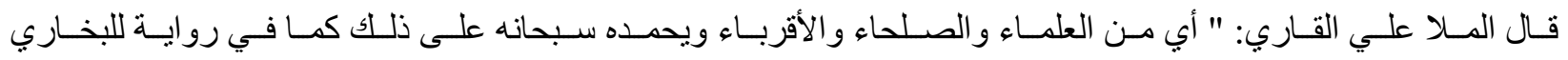

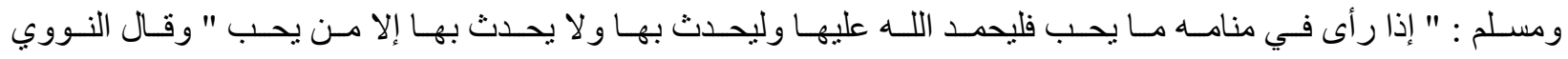

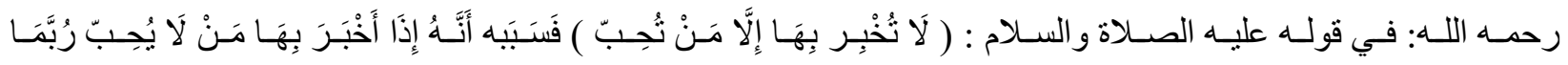

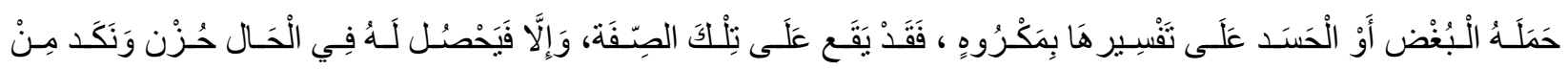

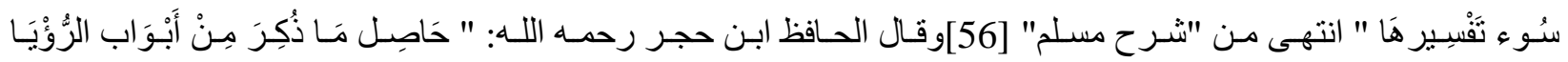

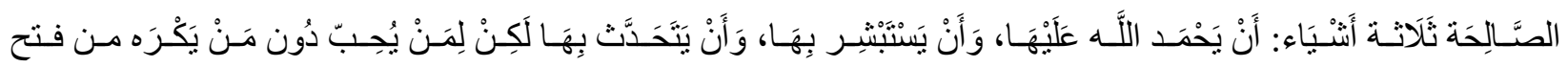
الباري. 


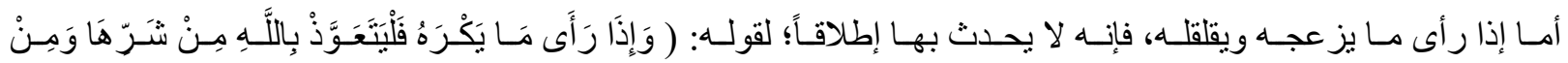

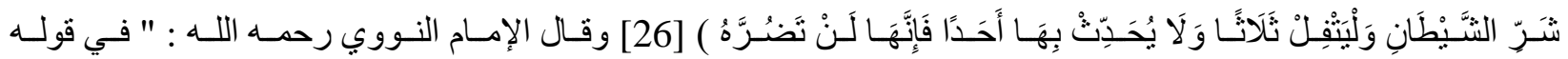

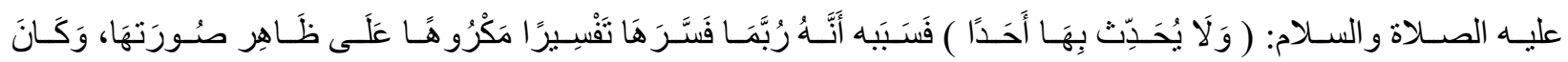

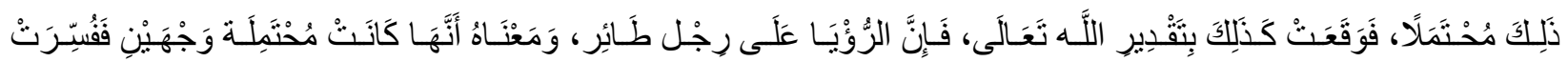

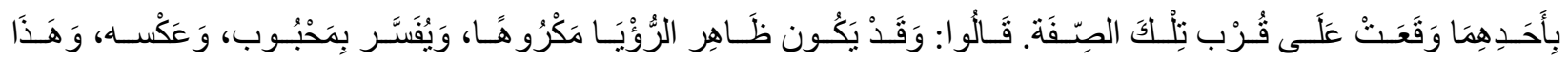

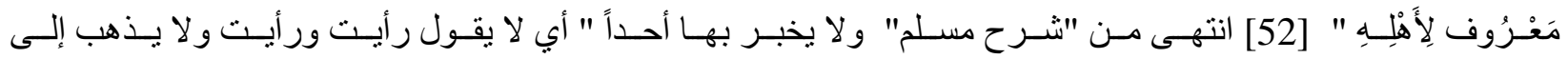

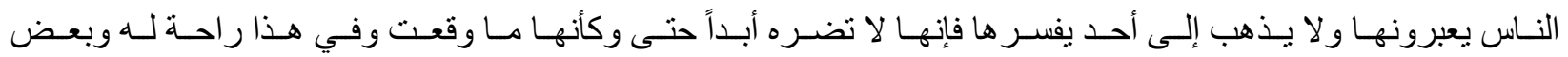

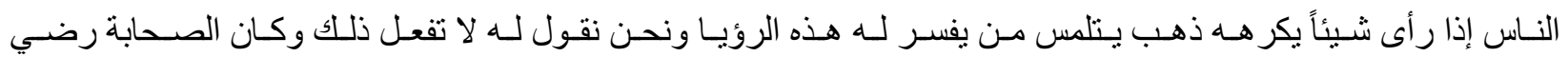

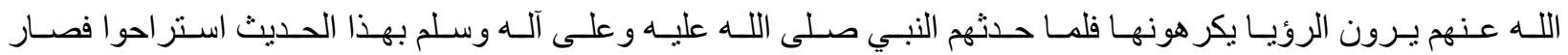
الإنسـان إذا رأى الرؤيسا التـي يكر ههـا بصـق عـن يسـاره ثـلاث مـرات واسـتعاذ مـن شـرها وشـر الثـــان ولـم يحدث بهـا أحدا ثم لا تضره وكأنه ما رآها " انتهى من شرح "رياض الصالحين" ـ [40]

\section{المطلب الثاني: مجاهدة النفس ودورها في كتمان السر في سورة مريم آية 26.}

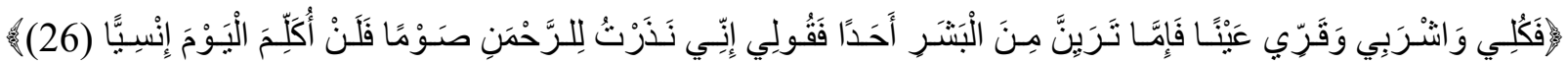
(سورة مريم: الآية26) ومن أهمية اعتز ال مريم الناس هي:

1-كفاها أسباب ما احتاجت إليه من أكلها وشربها، وسكّن من خوفها، وطيّب قلبها. [46]

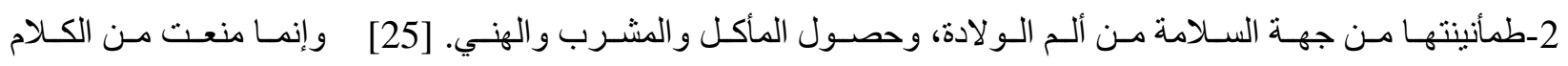
لأمور:

أحـدهما : أن يكون عيسـى عليـه السـلام هو المـتكلم عنهـا ليكون أقوى لحجتهـا في إز الـة التهـــة عنهـا وفيسه دلالـة على أن تفويض الكلام إلى الأفضل أولى.

و الثاني : كر اهة مجادلة السفهاء وفيه السكوت عن السفيه واجب إفلن أكلم اليوم إنسياً

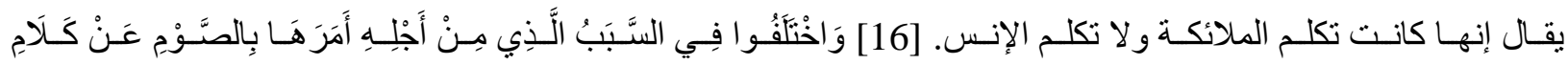

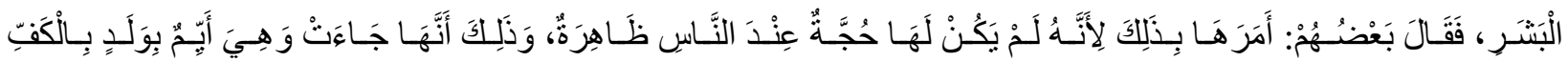




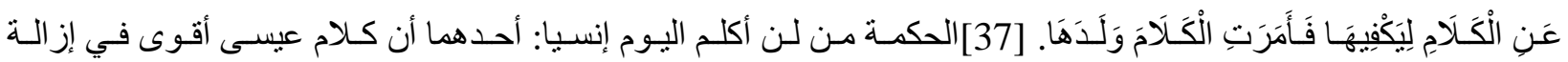

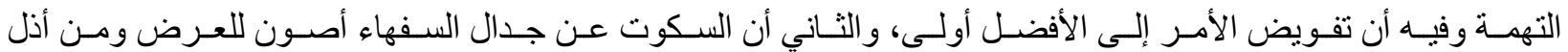
الناس سفيه لم يجد مشافهاً .

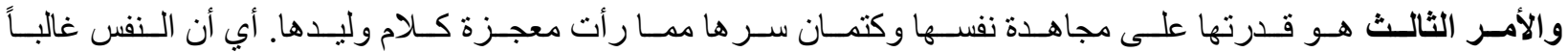

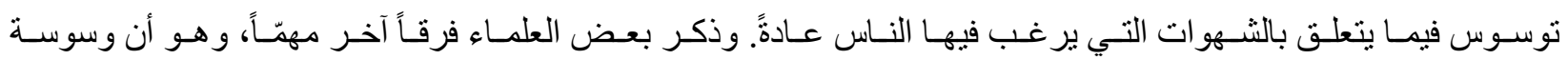

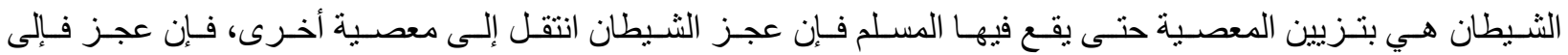
ثالثـة و هكذا ، فهو لا يهــهـ الوقوع في معصـية معينـة بقدر مـا يهمـهـ أن يعصسي هـذا المسـلم ربَّه، يسـتوي في هـذا فعـل

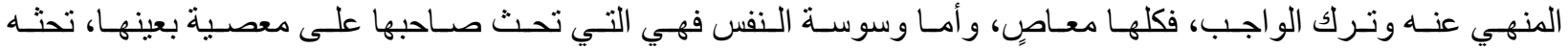
عليهـا وتكرر الطلب فيهـا. لكن مـريم عليهـا السـلام كانـت قـوة عزيمتهـا عاليـة فـي كتمـان السـر عـن النـاس وطاعـة لأوامر الله. وهو مأمور بجهادها، فإذا ما تهاون في جهادها واسترسل معها فإنه قد يؤاخذ على هذا التهاون .

\section{المطلب الثالث: مجاهدة النفس ودورها في كتمان السر في سورة القصص آية 10-13.}

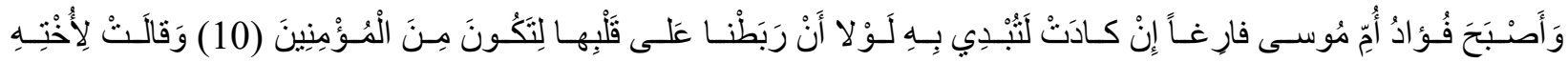

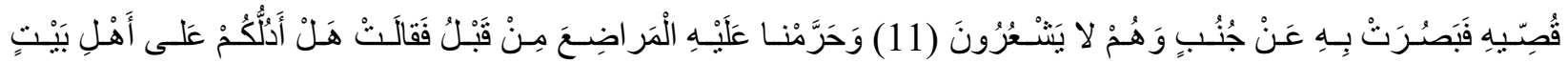

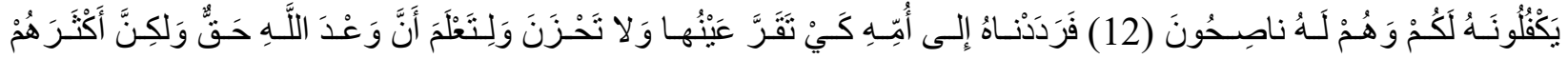
لا يَعْلَمُونَ (13) (سورة القصص: الايات من 10-13) .

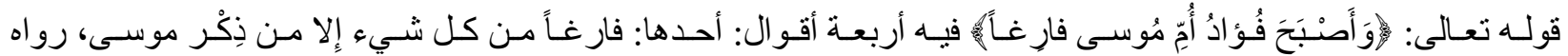
سعيد بن جبير عن ابن عباس، وبه قال مجاهد، و عكرمة، وقتادة، و الضحاك.

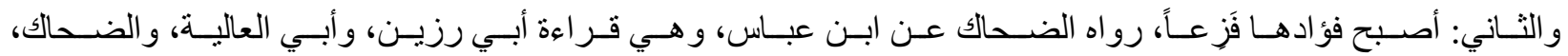

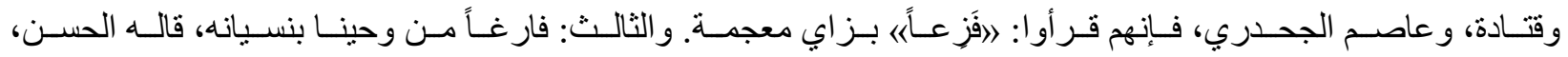

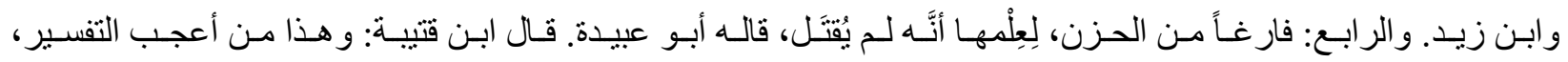

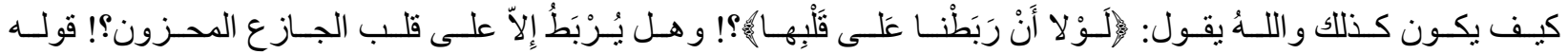

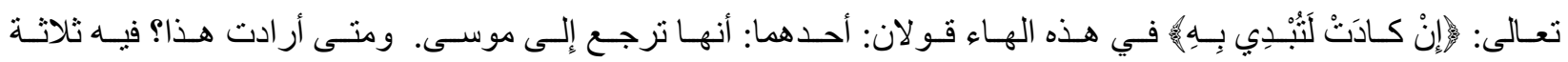

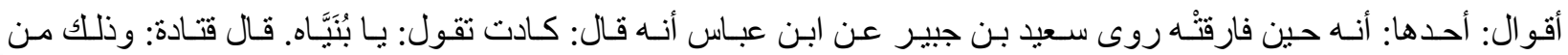




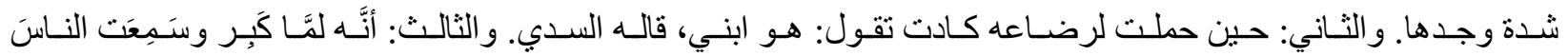
يقولـون: موسـى بـن فرعـون، كـادت تقـول: لا بـل هـو ابنـي، قالـهـ ابـن السـائب. والقـول التــاني: أنهـا ترجـع إلـى الـوحي

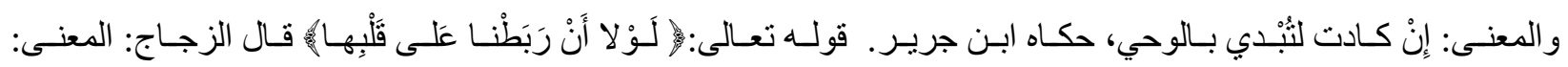

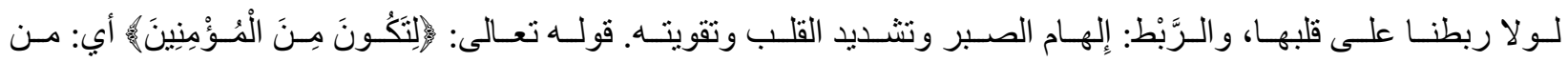

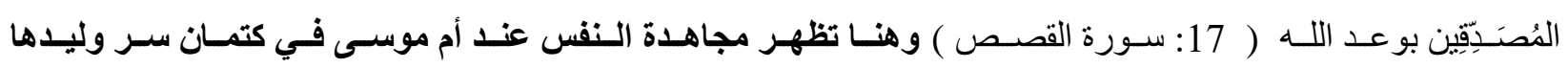

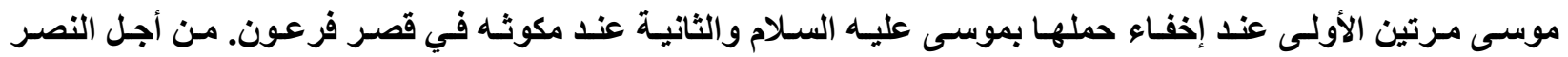
على الأعداء.

المطلب الرابع: مجاهدة النفس ودورها في كتمان السر سورة سبأ آية 14

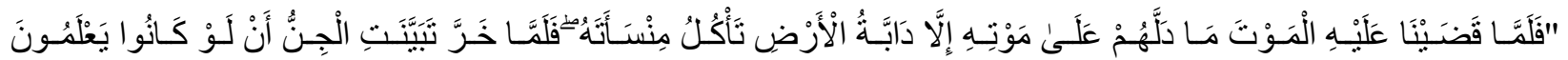
الْغَيْبَ مَا لَبِثُو افِي الْعَذَابِ الْمُهِينِ"

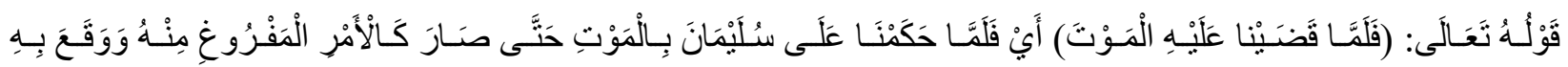

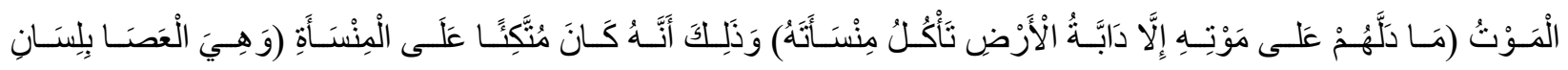

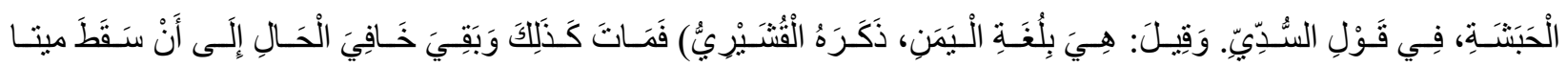

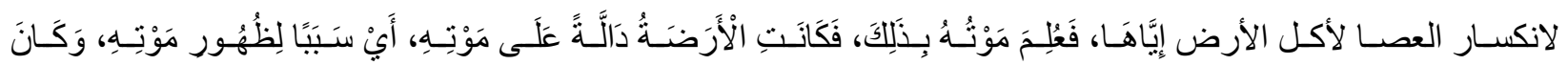

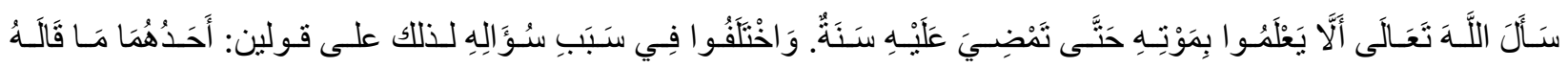

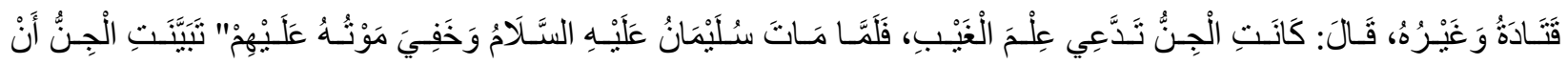

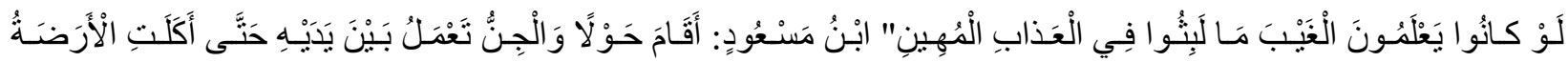

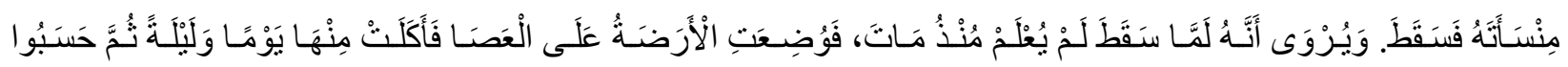

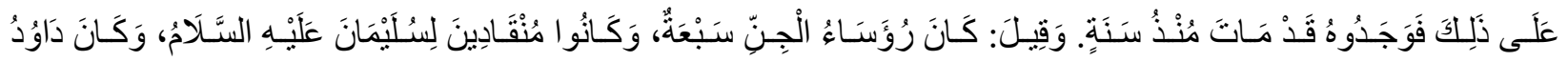

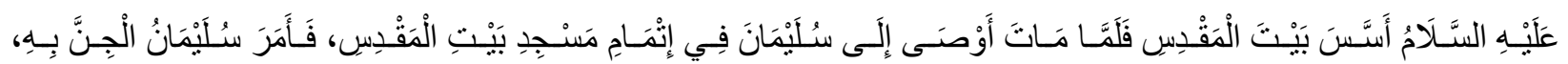

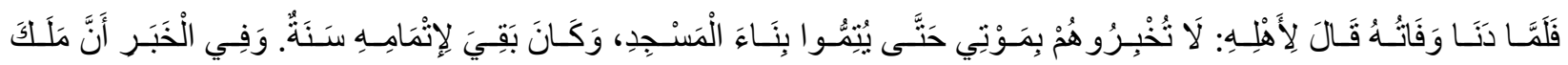

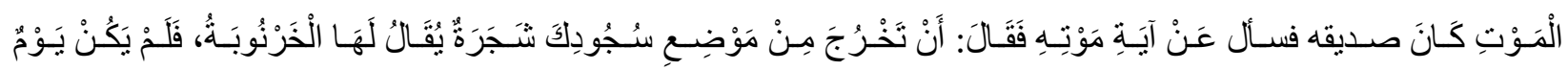

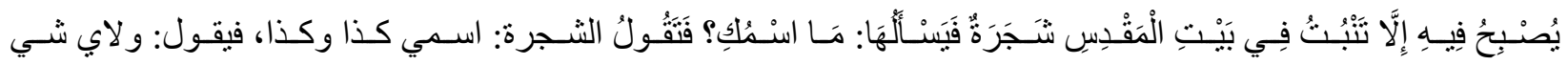




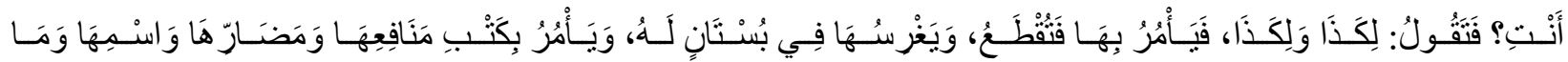

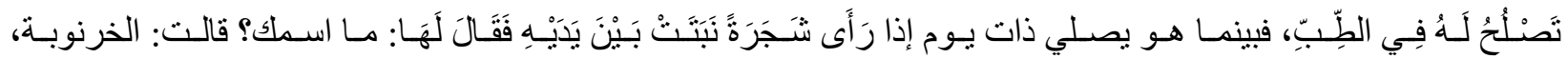

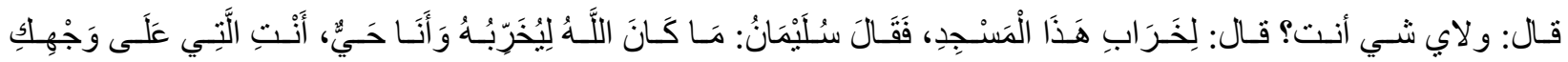

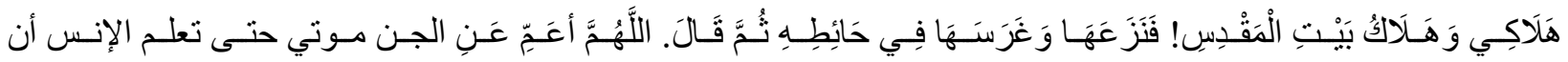

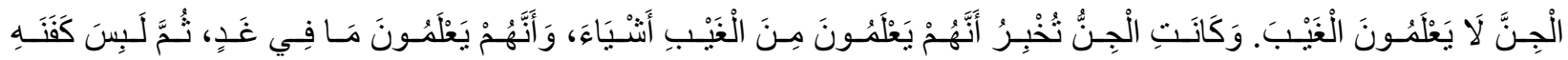

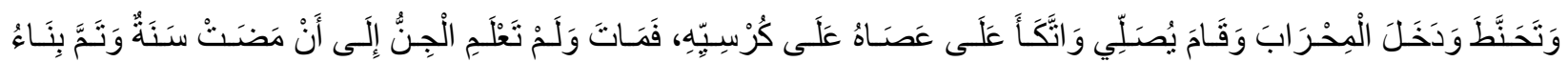
[45] الْمَنْجِدِ.

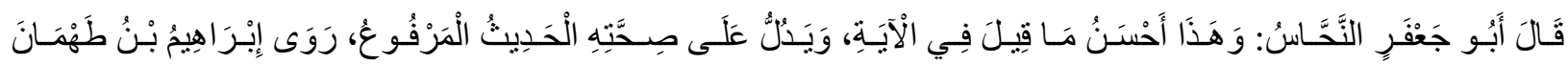

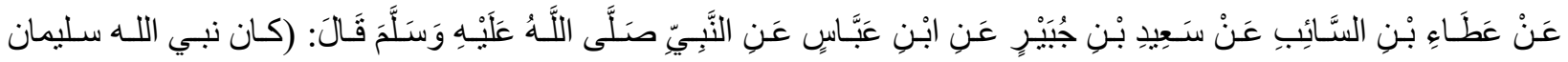

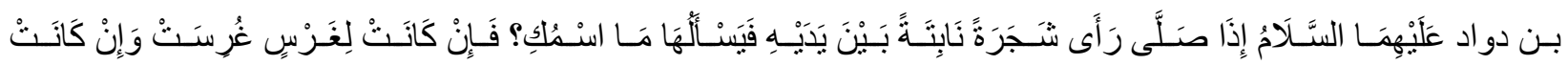

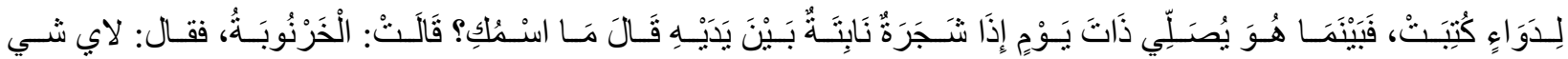

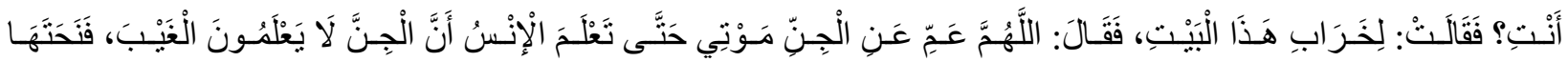

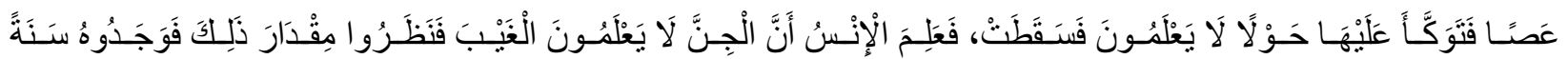

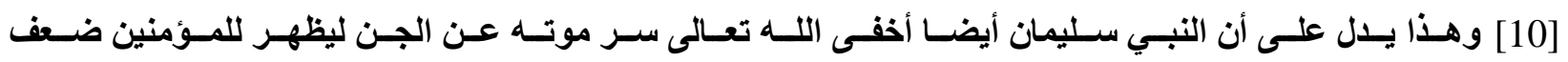
الثـياطين وكـذبهم فـي معرفـة الغيب وعـدم قدرتهم على معرفـة أسـرار الـنفس البشـرية إذا أخفى العبــ سـره بـين جنبيه.

- المبحث الثـاني: نمساذج مسن مجاهـدة النفس ودورهـا في كتمـان السـر في بعض سـور القرآن الكريم: سـورة طه آية 7، سورة فصلت آية34، سورة الحجرات آية 12، سورة ق آية 16-16. المطلب الأول: مجاهدة النفس ودورها في كتمان السر في: سورة طه آية7.

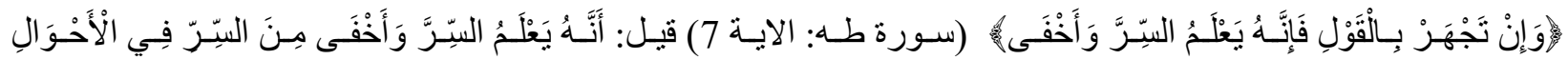

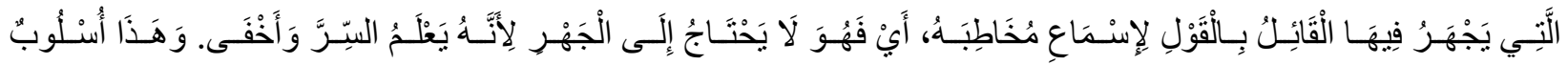

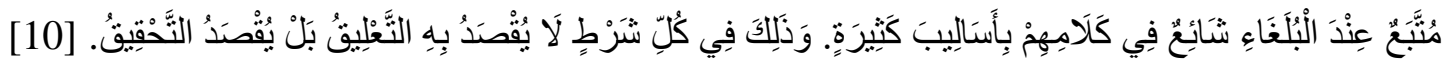




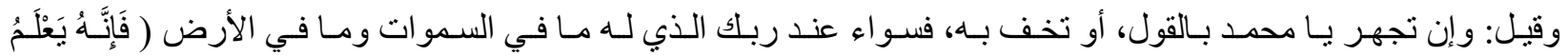

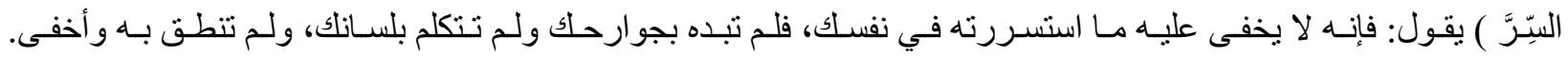

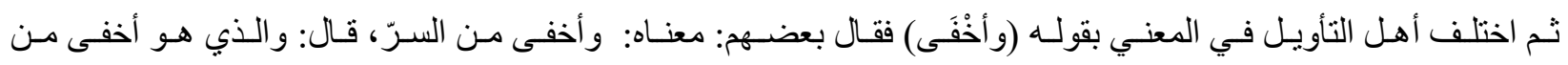

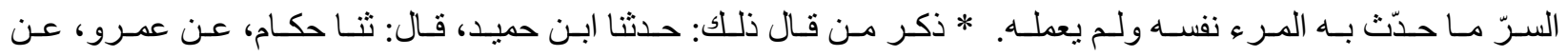

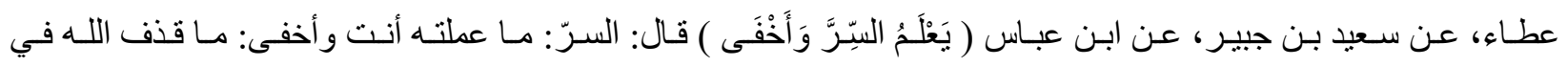
قلبك مما لم تعمله.

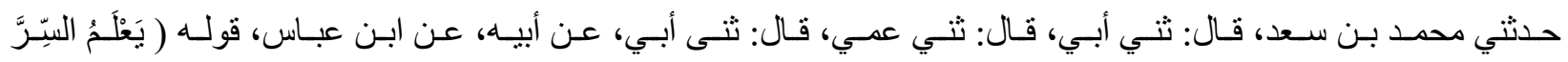

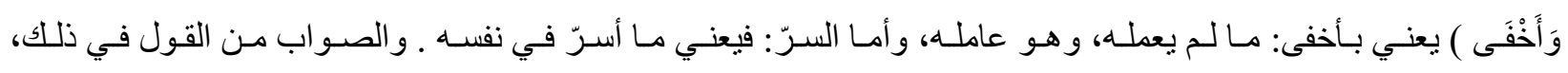

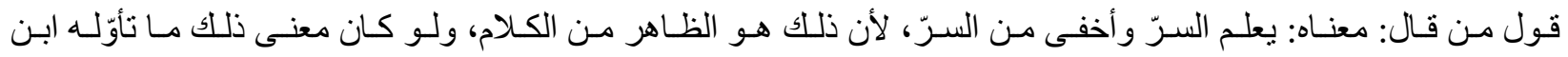

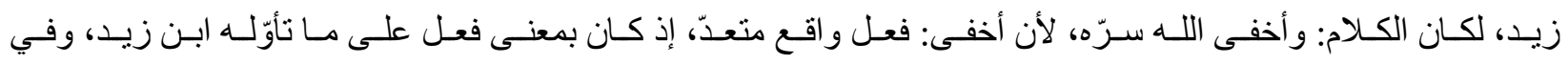

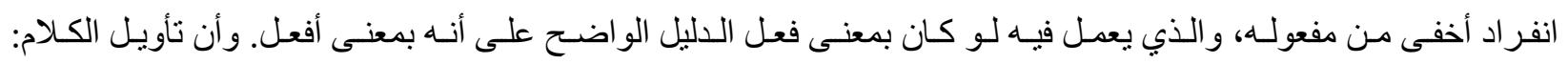

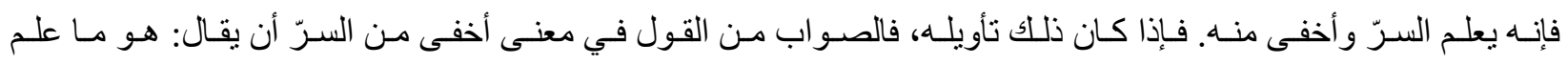

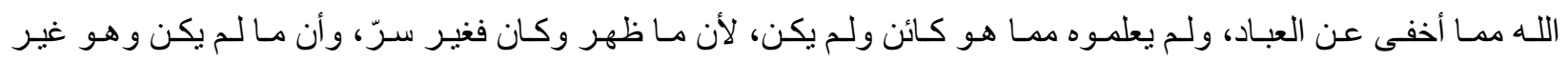
كـائن فـلا شـيء، وأن مـا لـم يكـن و هـو كـائن فهـو أخفى مـن السـرّ، لأن ذلـك لا بعلمـهـ إلا اللـه، ثـم مـن أعلمـه ذلـك مـن [38] [38]

\section{المطلب الثاني: مجاهدة النفس ودور ها في كتمان السر في سورة فصلت آية34}

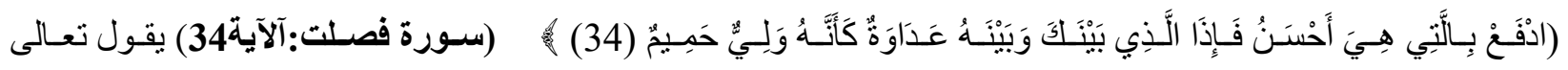

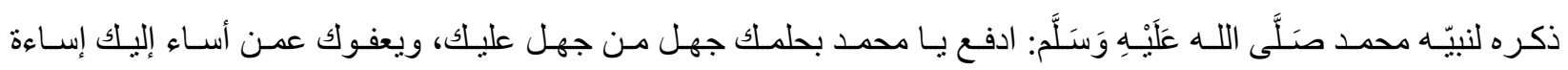
المسـيء، وبصـبرك عليهم مكروه مـا تجد منهم، ويلقـاك مـن قِبلهم. حدثني علـيّ، قـال: ثنـا أبو صـالح، قـال ثثـي معاويـة،

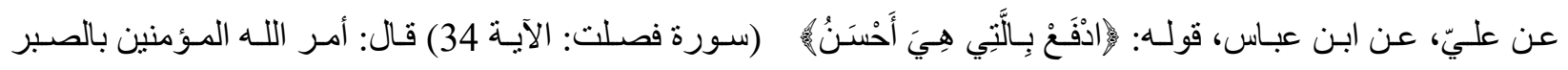

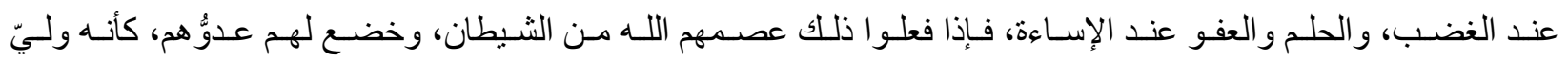

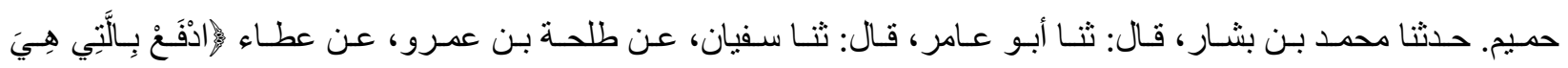
أَحْسَنْ 


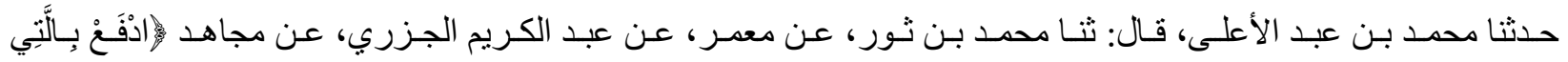

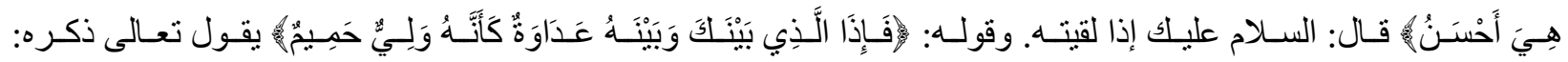

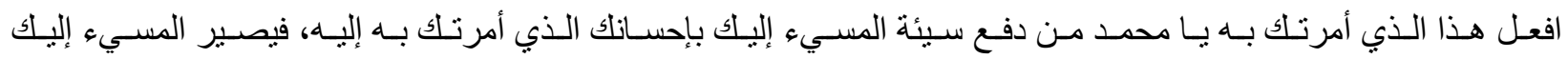

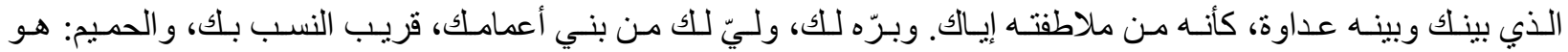

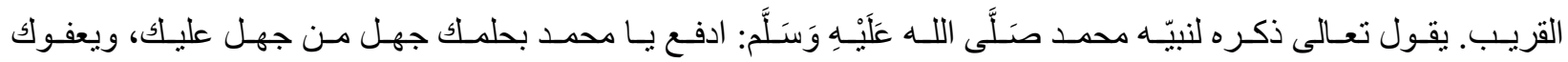

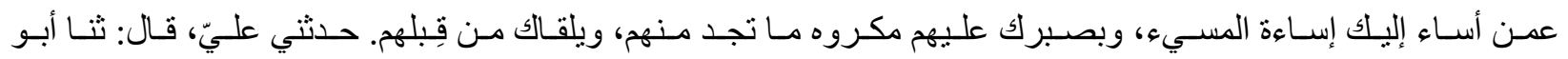

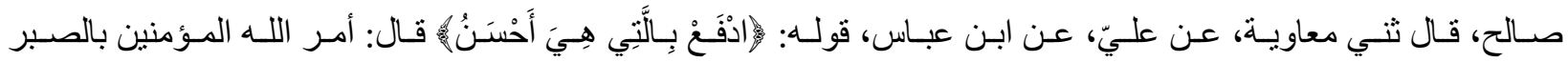

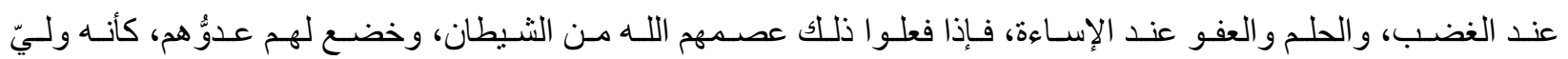
حمـيم (25: سـورة فصـلت )ومعنـى ذلــك إن كتمــان البغضــاء عـن الآخـرين وإفشــاء السـلام بـين الطـرفين يزيـل

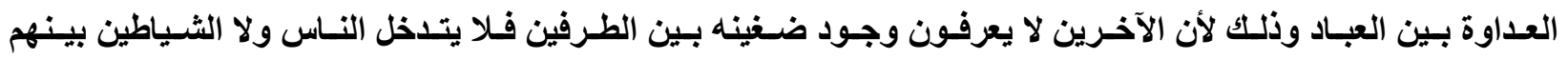
للوسوسة ولإثعال الفتن، ما دام الطرفين كتموا سر عداوتهم عن الناس.

المطلب الثالث: مجاهدة النفس ودورها في كتمان السر في ، سورة الحجرات آية 12 قال تعالى" و لا يغتب بعضكم بعضا" (سورة الحجرات آية: 12)

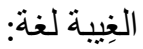

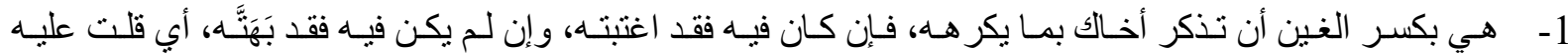
ما لم يفعله.

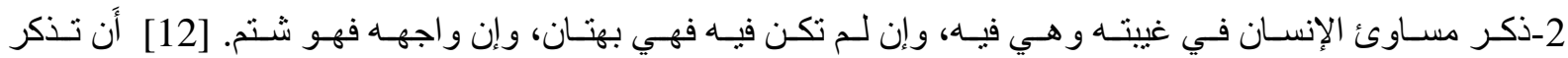

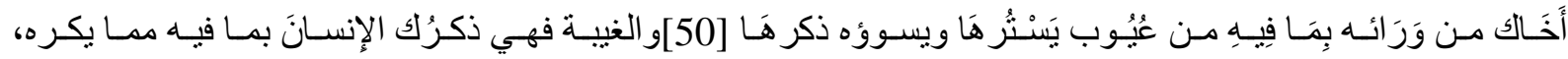

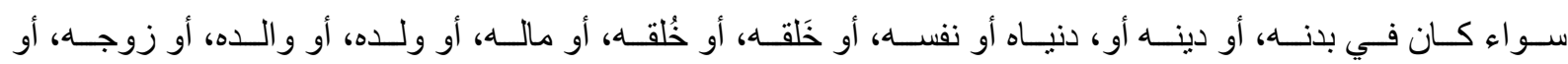
خادمــه، أو مملوكسه، أو عمامتــه، أو ثوبــه، أو مشـيته، وحركتـهـ وبشاشــته وخلاعتـه، و عبوســه، وطلاقتـه، أو غيـر

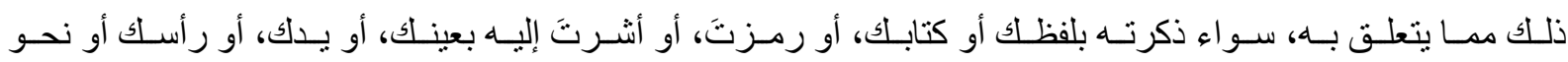
ذللك. [55] ومـن العلمـاء مـن يشـترط في الغيبـة أن يكـون المقول فيـه غائبـاً واللـه أعلم [44] و الغيبـة محرمـة بقول

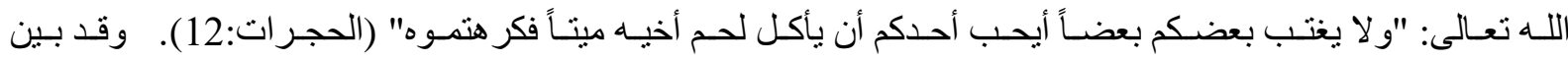




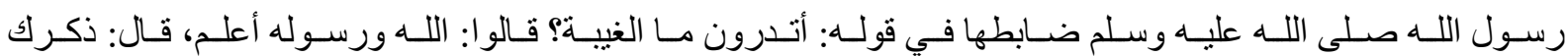

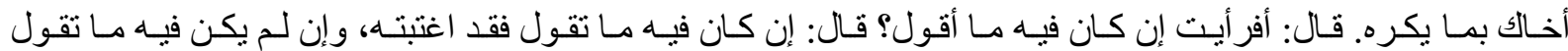

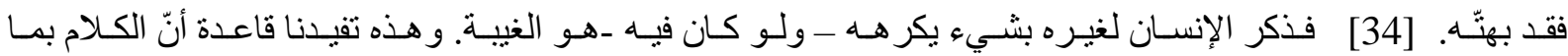

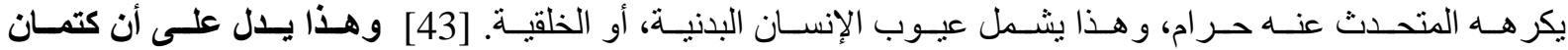

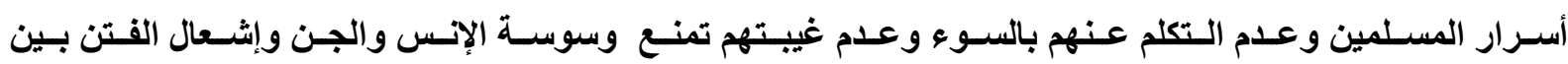

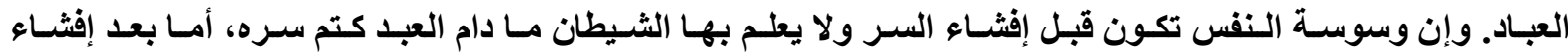
السـر فتظهر وسوسـة الثـيطان، لـللك لا يحاسـب اللـه على وسوسـة النفس وحتى الملائكـة لا تكتب الوسوسـة إلا

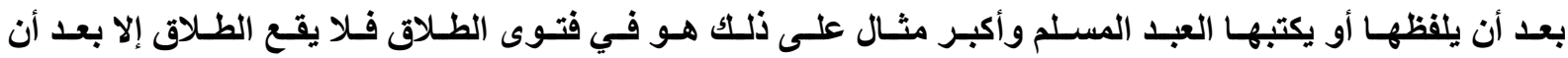
يتلفظ به أو يكتبه.

المطلب الرابع: مجاهدة النفس ودورها في كتمان السر سورة ق آية 16-16.

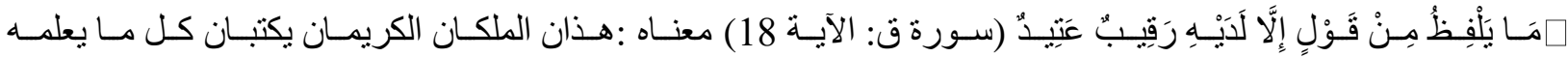

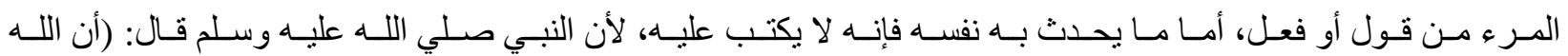
تجاوز لأمتي عما وسوست أو حدثت به أنفسها ما لم تعمل أو تكلم به). [13] لكن القول والفعل يكتب على الإنسان .

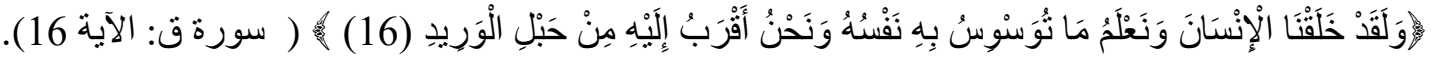

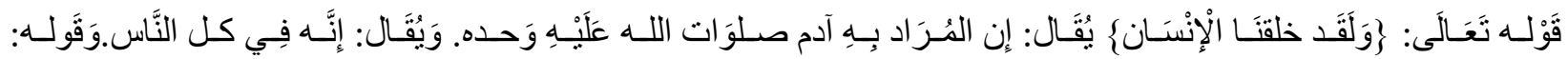

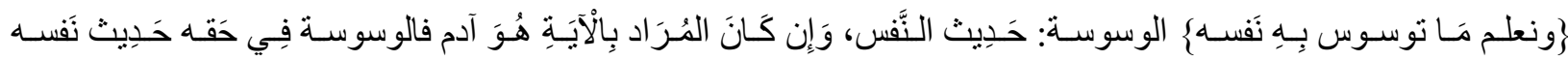

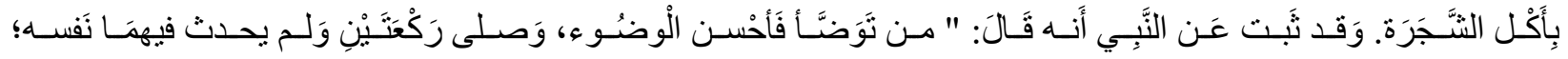

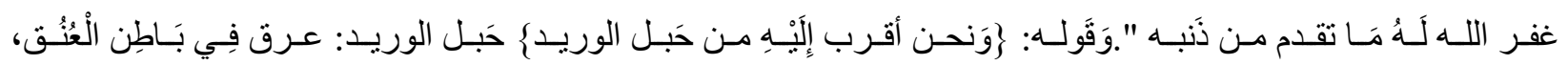

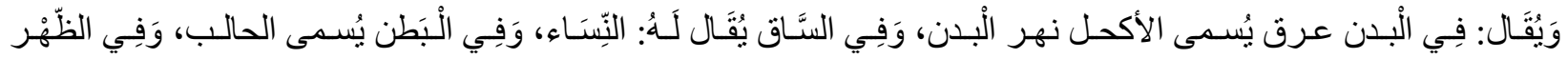

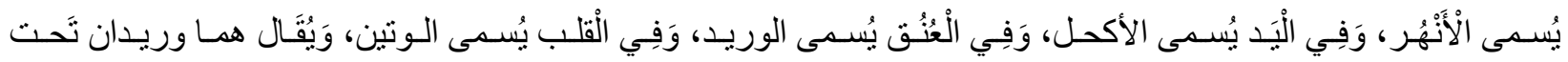

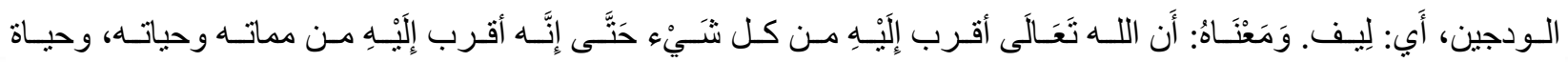




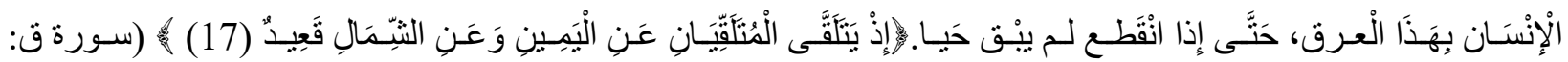

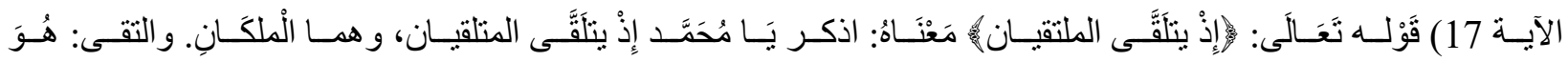

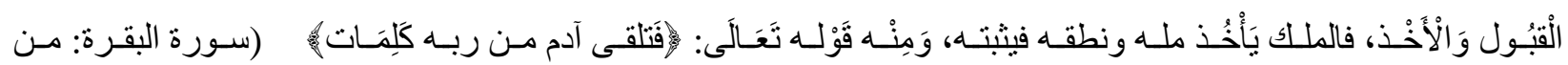

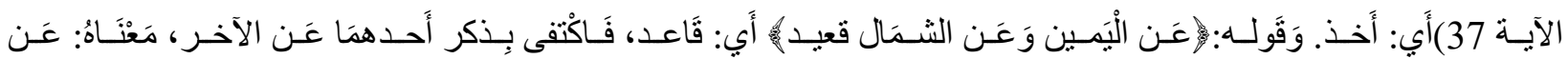

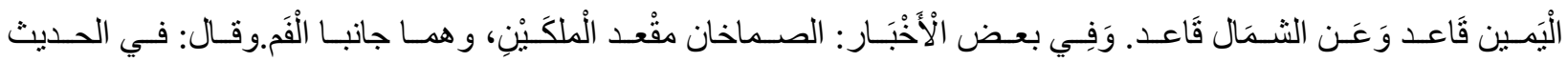
المـروي عن أبـي هريـرة رضـي اللـه عنـه قـال رسـول الله، صـلي اللـه عليهـ وسـلم : "إن اللـه تجـاوز لأمتـي مـا حدثت بهـا

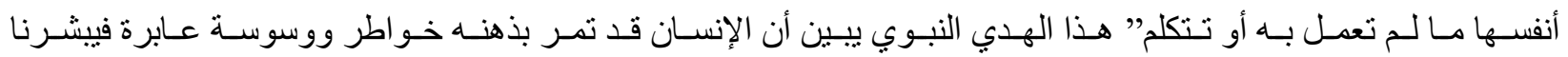

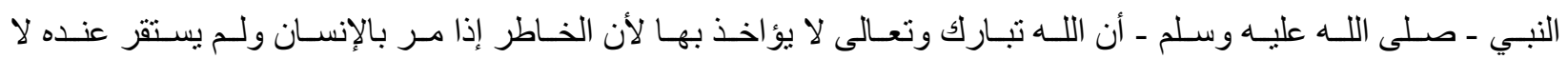

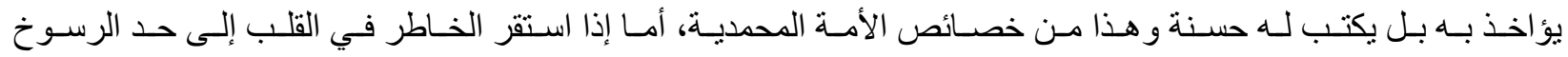

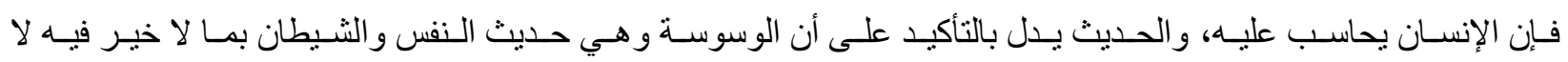

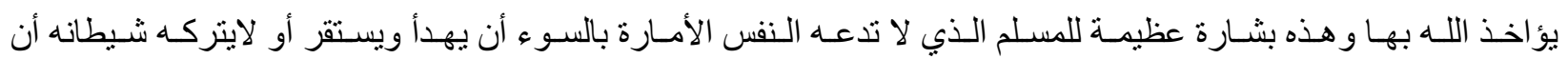

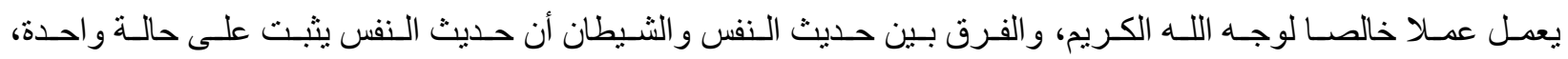

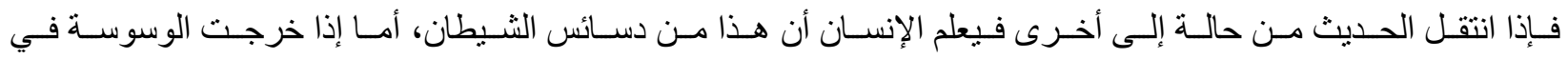
صورة عمل أو كلام فيؤاخذ الله عليها. [29]

- المبحث الثالث: نماذج من مجاهدة النفس ودورها في كتمان السر في فتوى الطلاق: المطلب الأول: نموذج من مجاهدة النفس ودورها في كتمان السر في فتوى الطلاق.

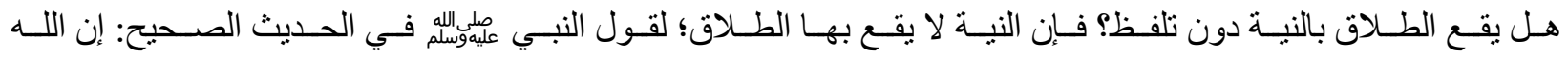

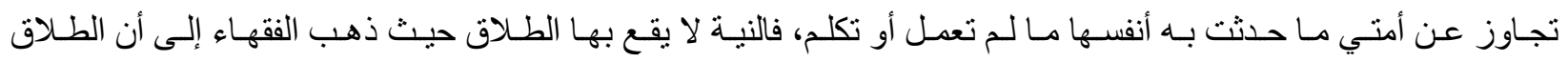

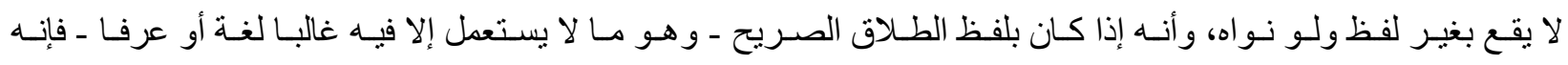

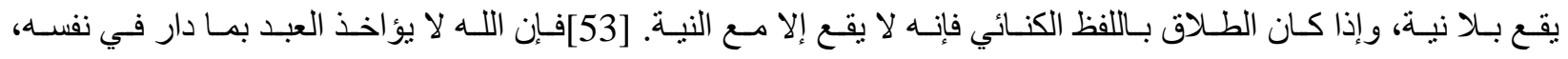

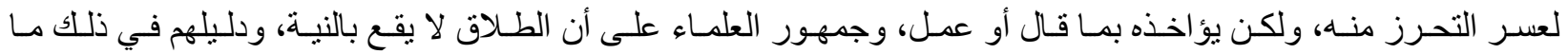
رواه البخـاري في صـحيحه، عـن أبـي هريـرة رضــي اللـه عنـهـ عـن النبـي صـلى اللـه عليـه وسـلم قـال: " إن اللـه تجـاوز عن أمتـي مـا حدثت بـه أنفسـها، مـا لـم تعمـل أو تـتكلم " (اخرجـه البخـاري، د.ت: 5269).قـال قتـادة : إذا طلق في نفسـه فليس بشيء قال ابن حجر : الطلاق لا يقع بالنية دون اللفظ انتهى. [9] 


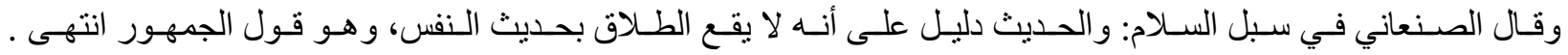

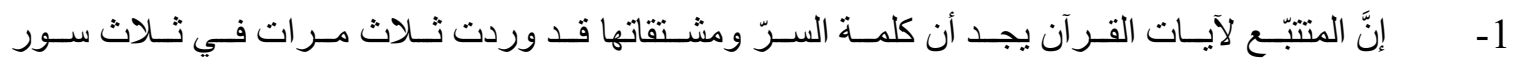

$$
\text { وتكررت كلمة الغيب في القرآن الكريم(40) مرة في (31) سورة. }
$$

إن وسوسـة النفس تكـون قبـل إفثــاء السـر و لا يعلـم بهـا الثـبطان مـا دام العبد كتم سـره أمـا بعـد إفثــاء

السـر فنظهـر وسوسـة الثـبطان، لــللك لا يحاسـب اللـه على وسوسـة الــفس وحتـى الملائكـة لا تكتـب

الوسوسـة إلا بعـد أن يلفظهـا أو يكتبهـا العبـد المسـلم وأكبـر مثــال على ذلـك هـو فـي فتـوى الطـلاق فـلا

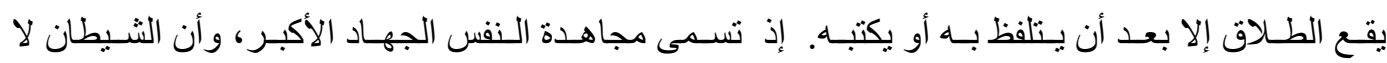
يعلـم مـا تسـر بهـا نفس الإنسـان البشـرية ومـا تخفيهـا ـ مصـداق قولـه تعـالى في (سـورة سـبأ آيـة 14)"

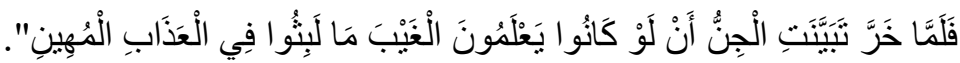

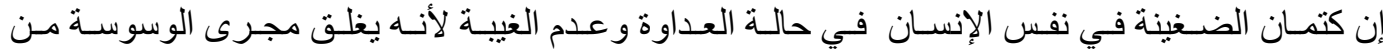

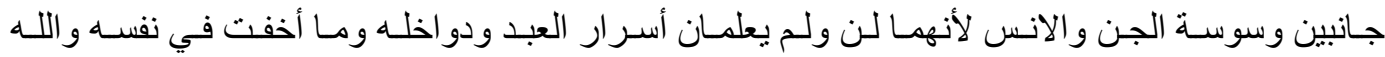

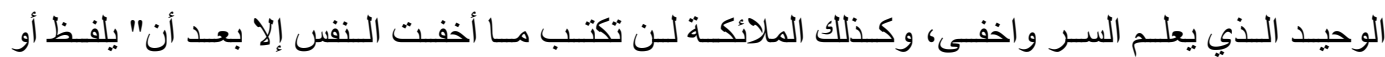

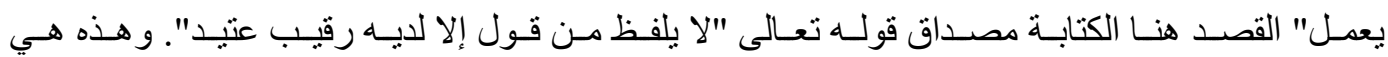
فتوى الطلاق الذي لا يقع على المراة إلا بعد التلفظ أو الكتابة.

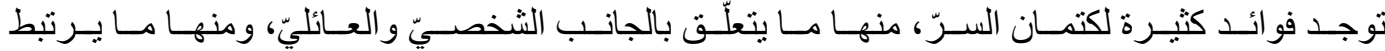
بالجانب السياسيّ و الاقتصاديّ، ومنها ما يرتبط بالجانب الأمنيّ و العسكريّ، والجانب الدينيّ. 5- يحرم الإفثاء في عدة موارد نشير إليها إجمالاً، وهي: إفثاء سرّ المؤمن وإذاعته، إفثاء الفاحشة.

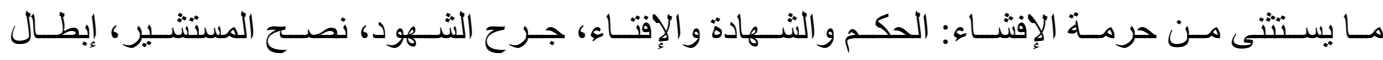
البدع و الأباطيل.

من دو افع إفشاء السرّ: العُجب والفخر ، النكاية أو التشهير، الخيانة.

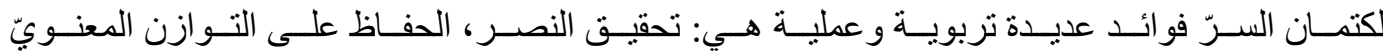
$-8$ ل المجنمع، نجاح الأمور، توثيق الصلة بالإخوان. 


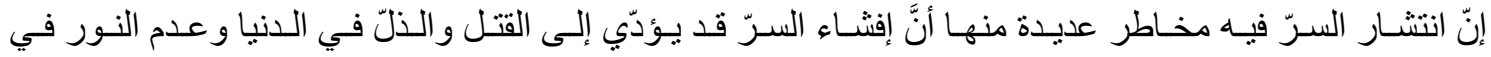

الآخرة، كما أنَّه يُعدُّ إيذاء الآخرين، وضرر في كثير من المجالات.

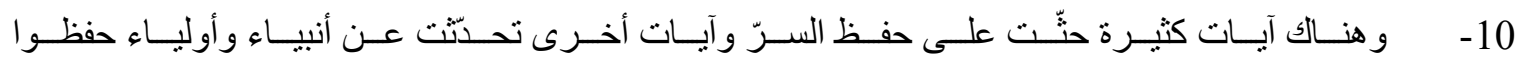

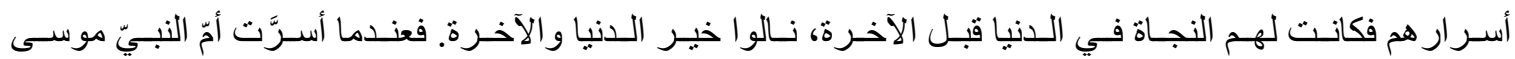

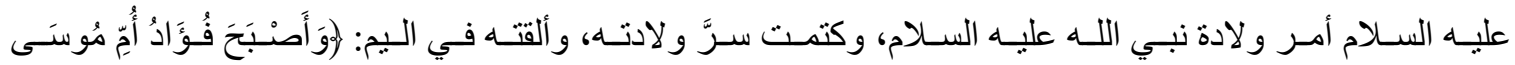

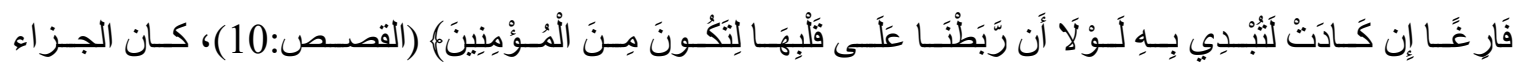

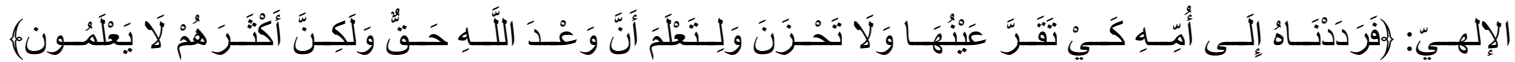
(القصـص: 13). وحين قصنَّ نبـيّ اللـه يوســ عليـه السـلام رؤيساه على أبيـه النبـيّ يعقوب عليـه السـلام، أوصــاه

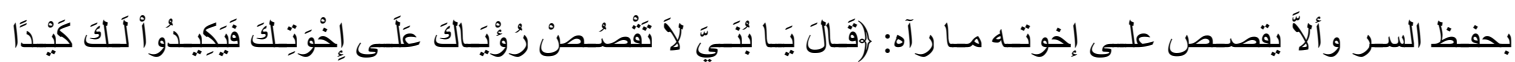

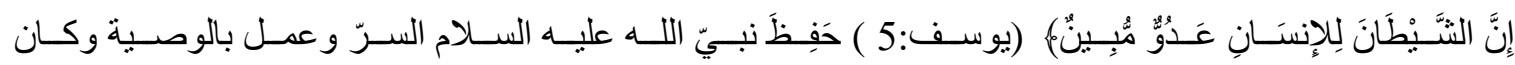

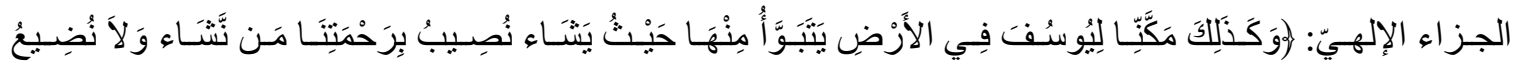

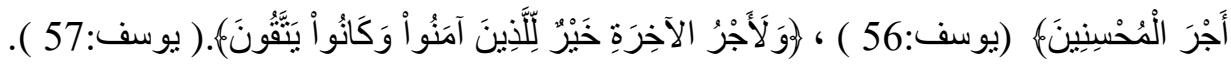
11 - كتمان قضاء الحاجات : من يريد أن يقوم بعمل ما، عليه أن يكتمه وأن لا يحدث به كل أحد حتى يقوم بإكماله . وكما قال رسول الله صلى الله عليه و آله وسلم قال: (استعينوا على إنجاح حو ائجكم بالكثمان فإن كل ذب نعمة محسود[20] 12ـكتمـان الأسـرار الزوجيـة والأسـرية مـن الأمسور (التـي يجـب حفظهـا وعـدم إفثـائها... فهـو أولًا : حـق المـر أة في

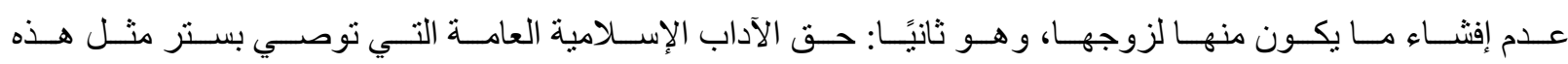

$$
\text { الأمور الأسرية والزوجية. }
$$

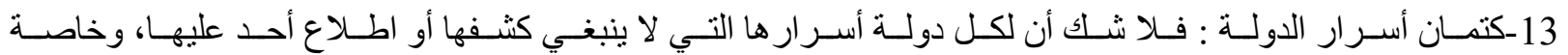

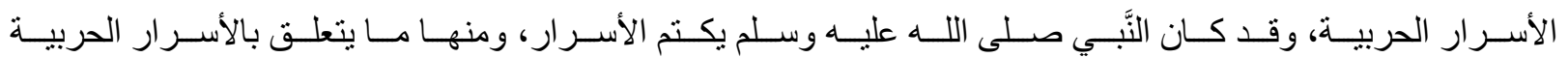
و العسكرية، فكان من هديه إذا أر اد غزوة ورَّى بغير ها. [8] التوصيات: وفي ضوء نتائج البحث تم وضع بعض التوصيات هي: 


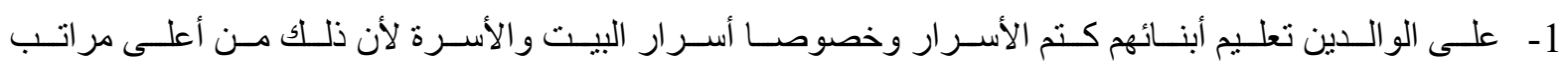
مجاهدة النفس.

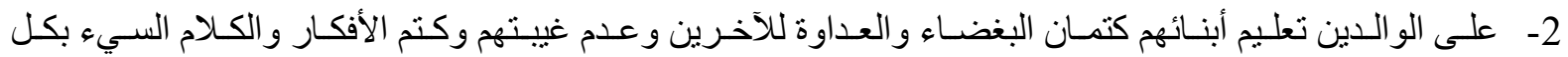

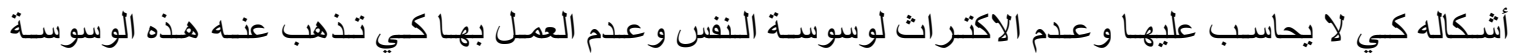
تدريجيا إذا درب نفسه على إهمالها مرارا.

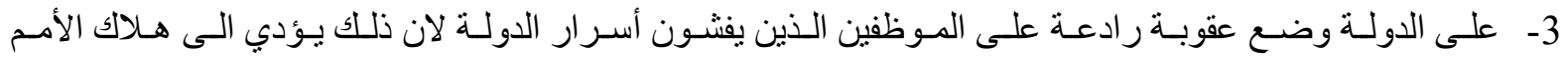
و الحضار ات.

4- أن يعـود كـل مسـلم نفسـه على حفظ أسـر اره الخاصـة و العامـة و لا يبـوح بهـا أمسام الآخـرين أو يـتكلم بهـا بصـوت

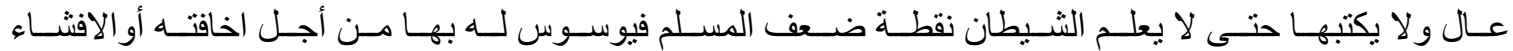
بأسـر اره أمسام أعـداءه، خصوصــا إذا كانــت أفكـار المسـلم حـول خطـط مسـتقبلية أو غيبـة مسـلم آخـر أو عداوتــهـ للآخرين. 


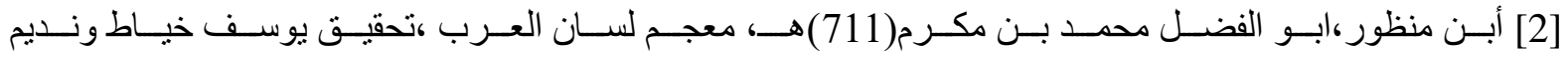

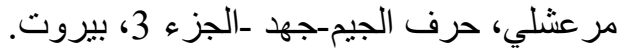

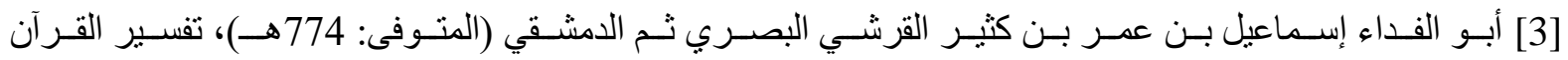

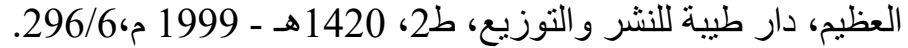

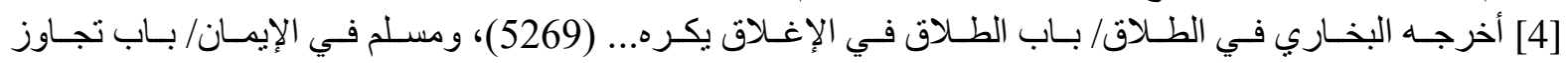

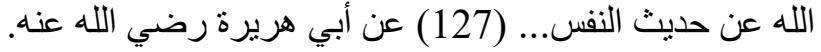

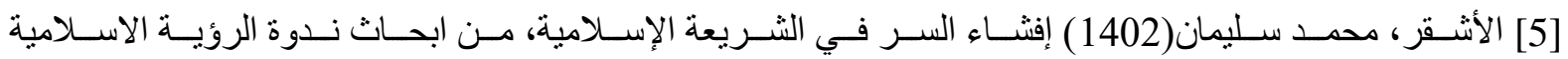

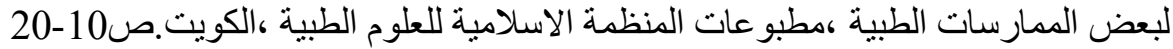

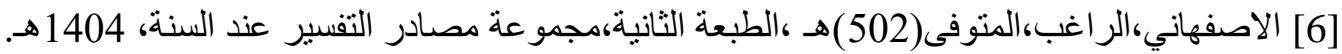

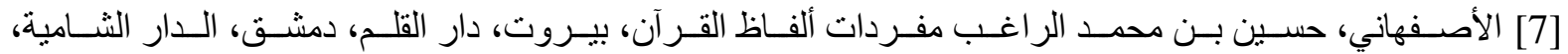

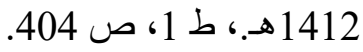

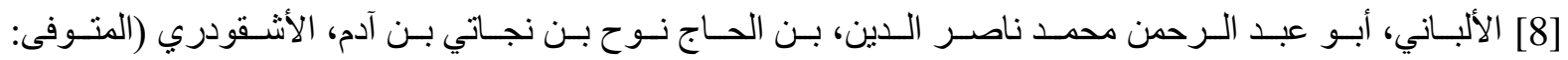

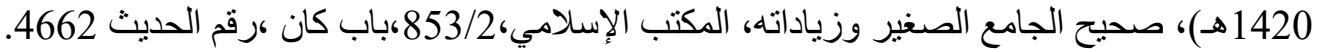

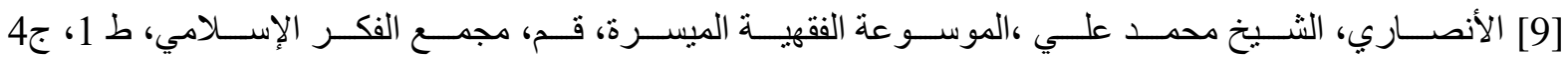

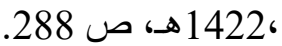

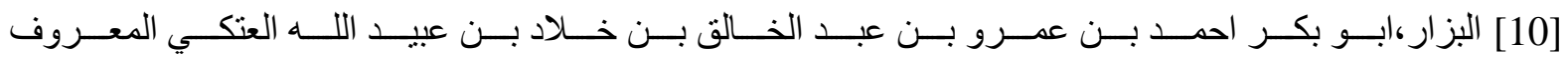

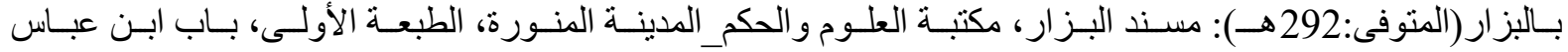

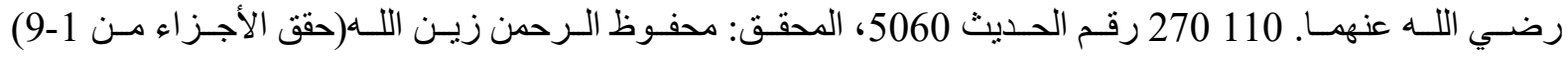
و عادل بن سعد(حقق الأجزاء من 10-17) وصبري عبد الخالق الثافعي(حقق الجزء 18).

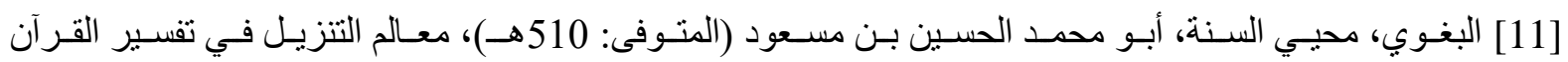

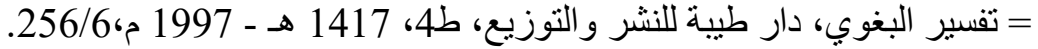

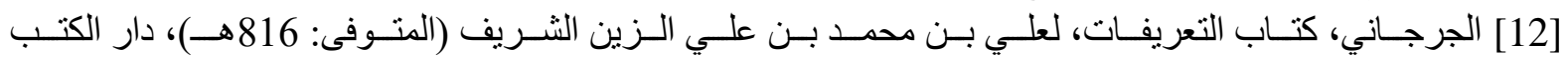

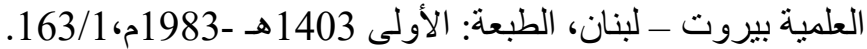

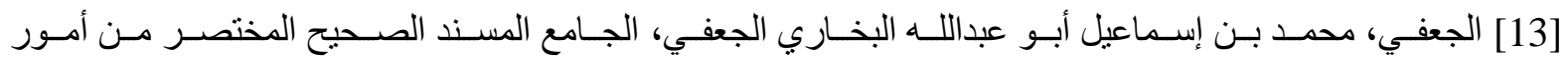

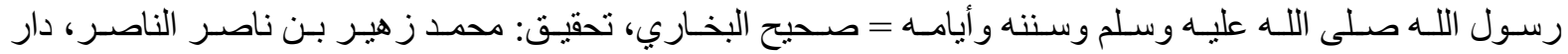

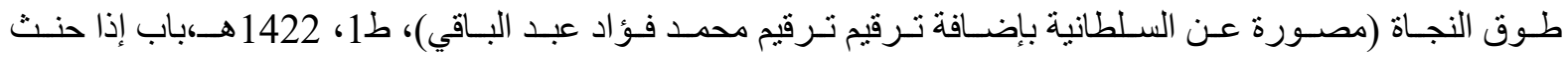
ناسيا في الإيمان،135/8، 13قرة

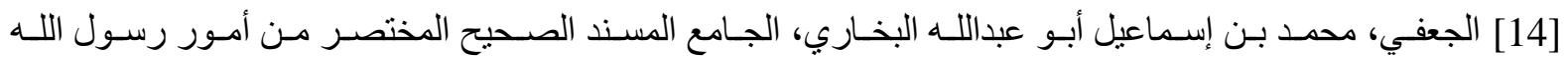

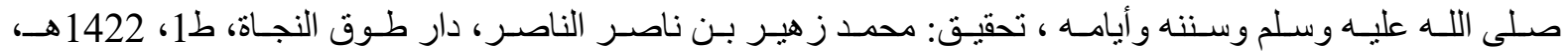

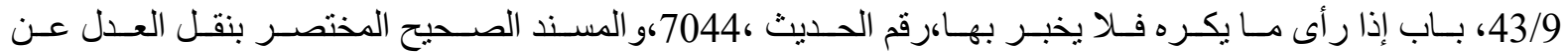

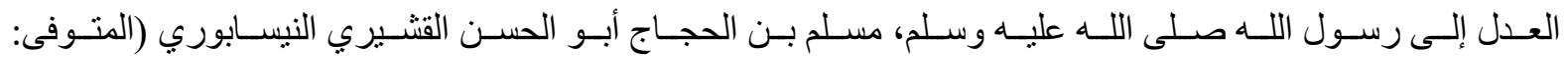

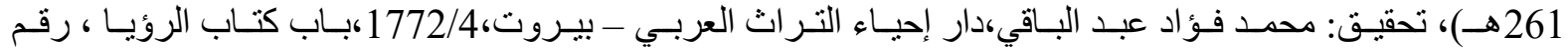

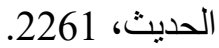

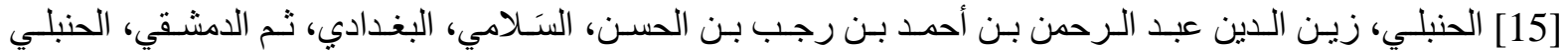

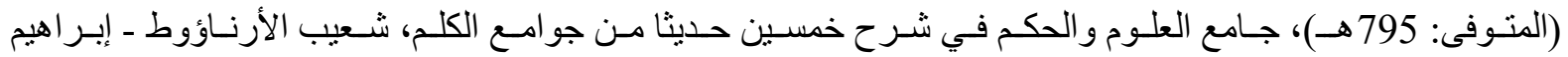

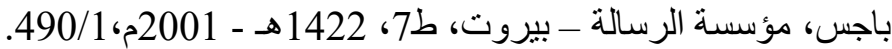

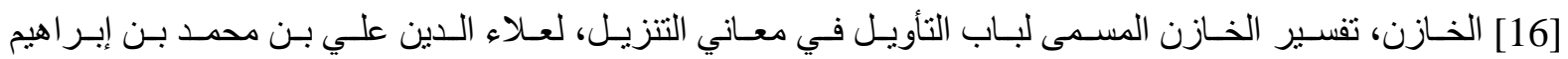

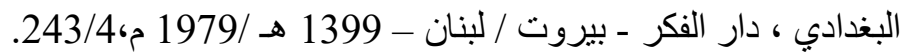
[17] الدمشقي،الامام عماد الدين ابي الفداء اسماعيل بن كثير القرشي المنوفى(774)ه.تفسير ابن كثير. 


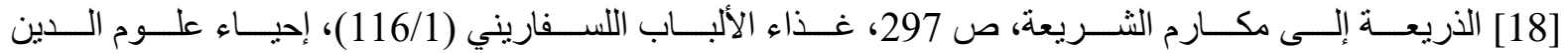

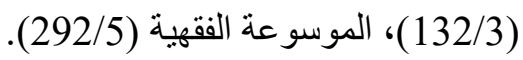

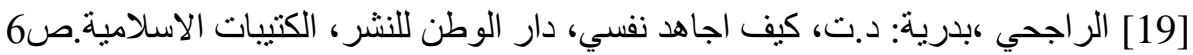

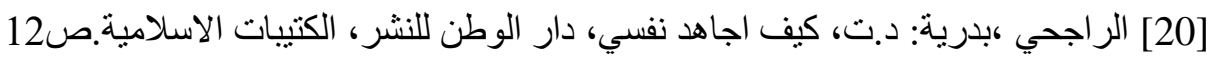

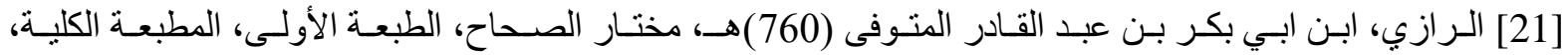

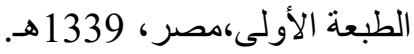

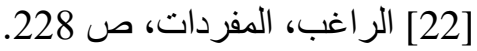

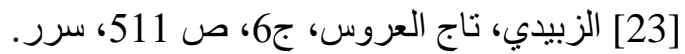

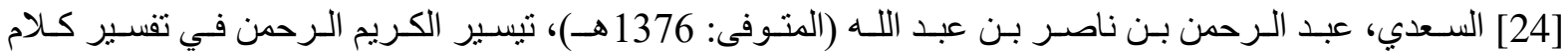

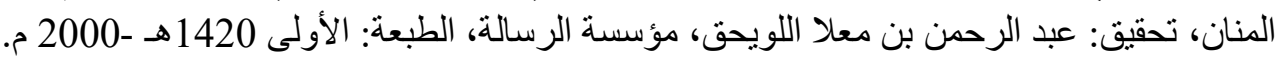

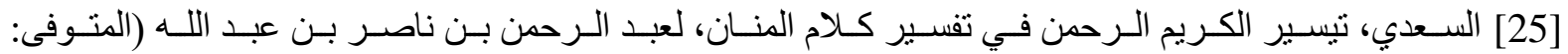

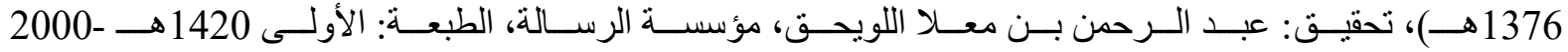
$.492 / 1$ م

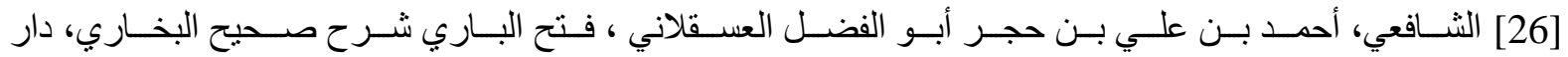

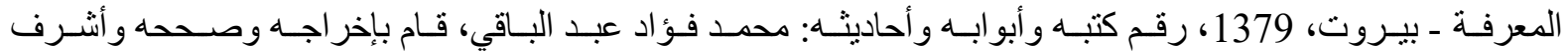

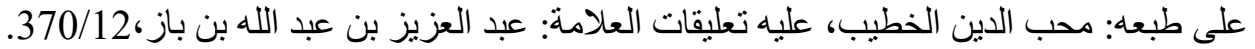

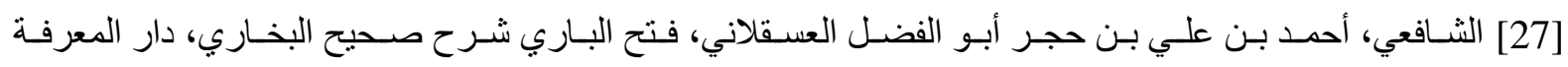

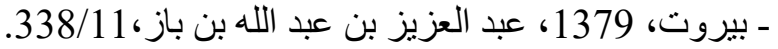

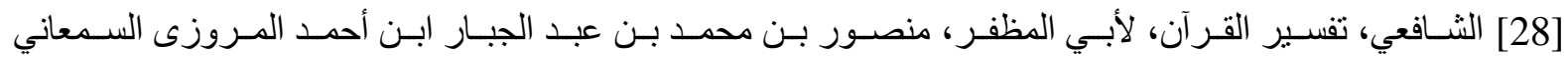

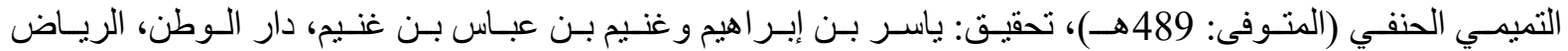

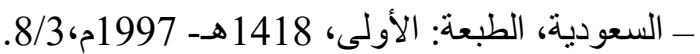

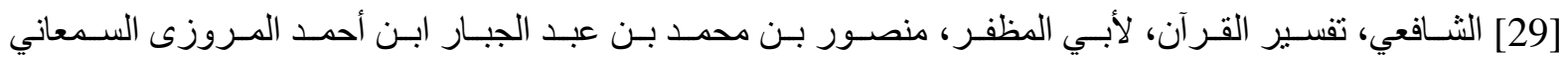

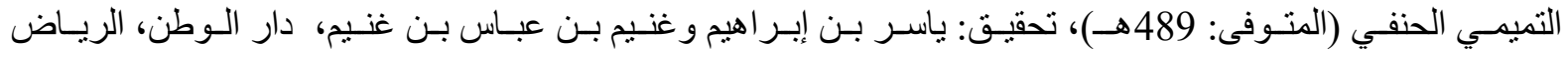

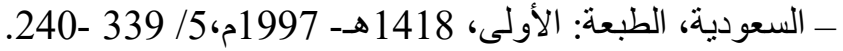

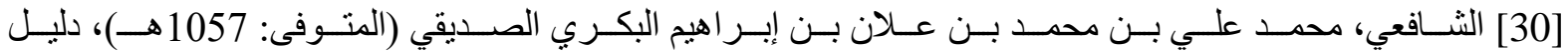

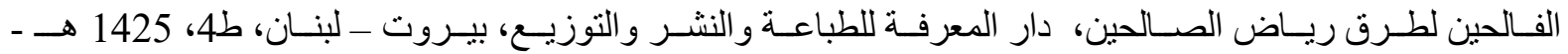
308/2 2004

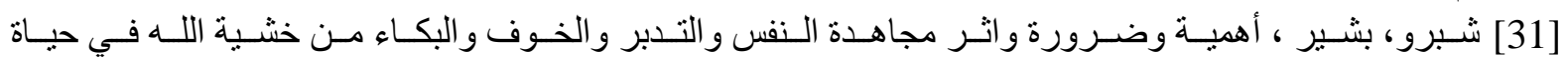

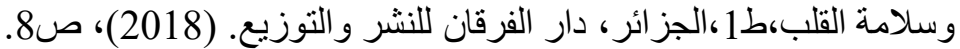

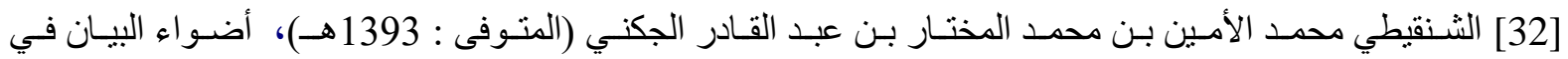

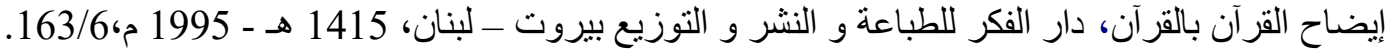

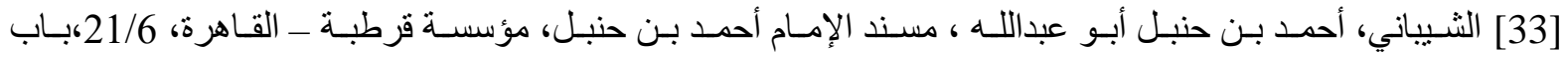

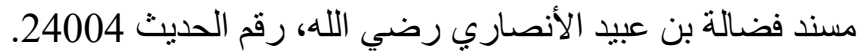

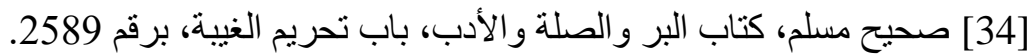

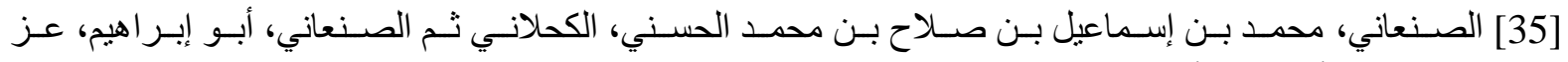

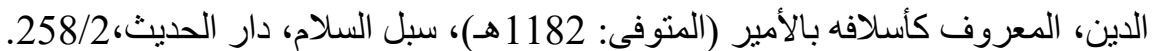

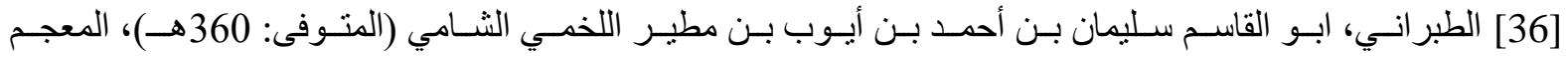

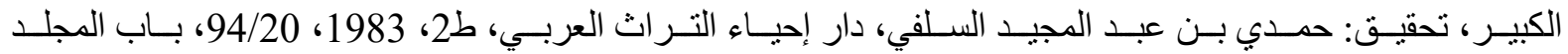

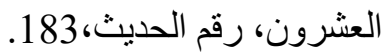

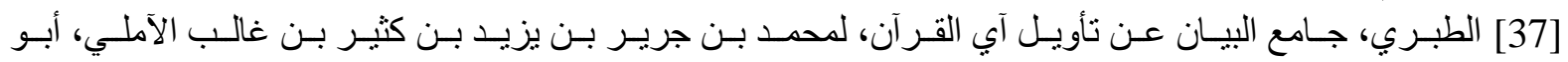

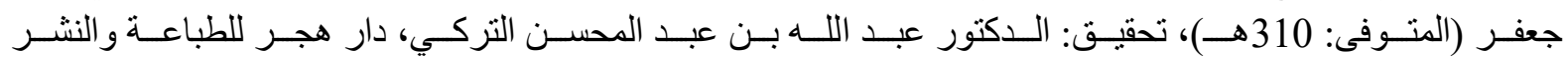

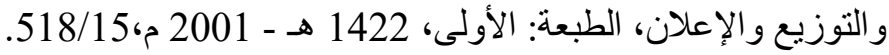




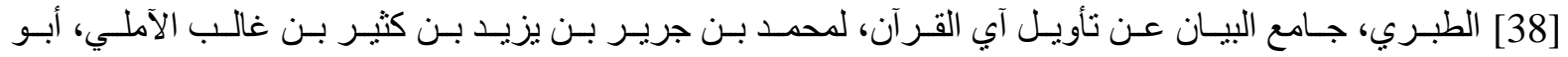

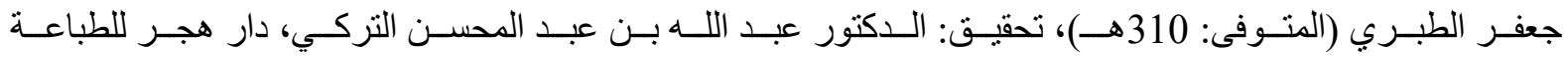
والنشر والتوزيع والإعلان، الطبعة: الأولى، 1422 هـ - 14201001 م. 2001 م.274/18.

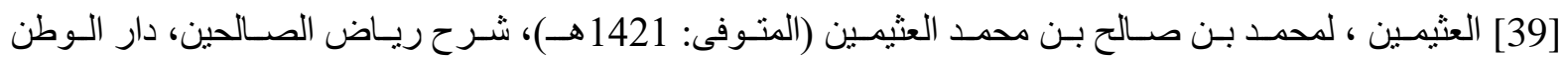
للنشر، الرياض، الطبعة: 1426هـ، 467/1،

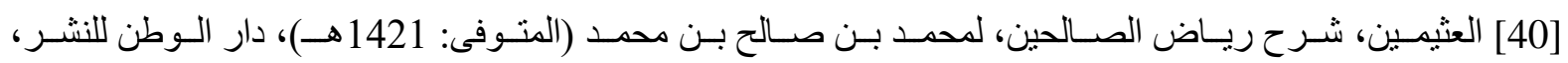

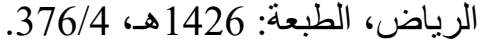

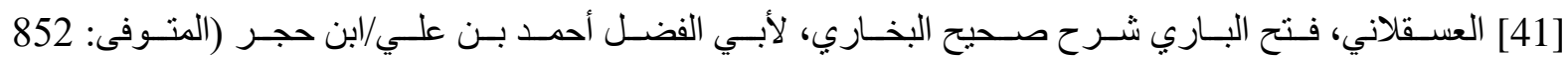
هـ)، دار الكتب العلمية، بيروت ـ لبنان، 1379 هـ، 1937 لـ 337.

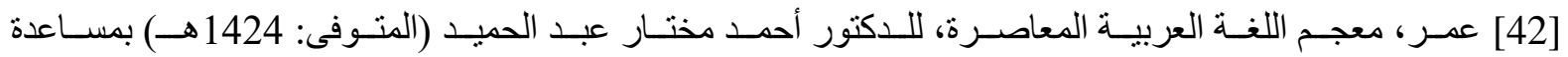

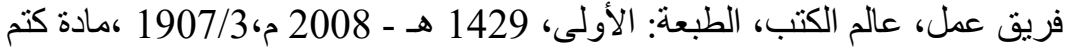

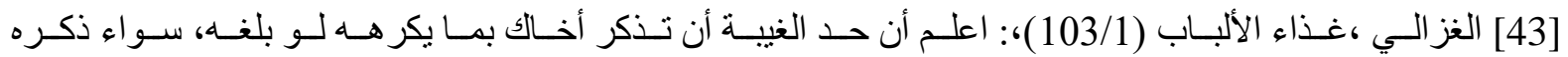

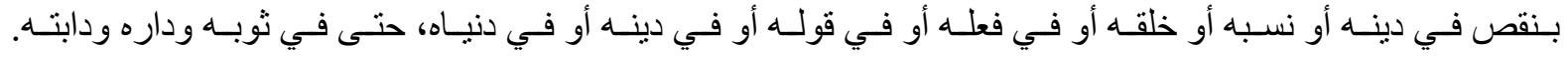
أنظر : إحياء علوم الدين (129/3).

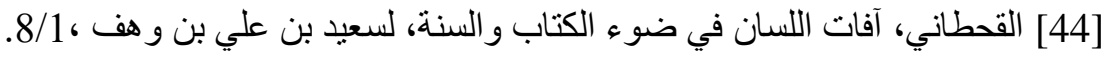

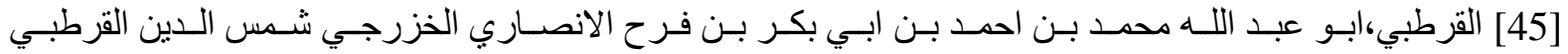

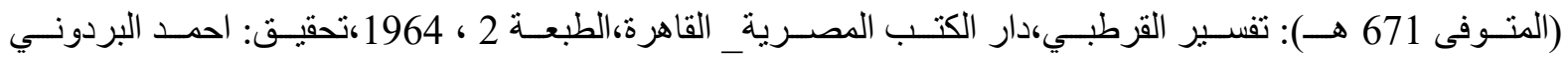
و وابر اهيم اطفيش، الصفحات: 278-279.

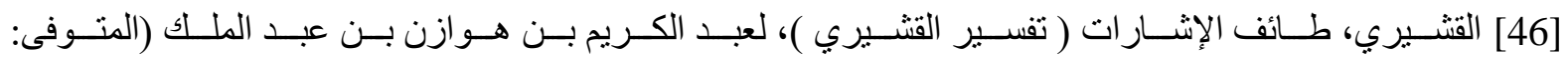

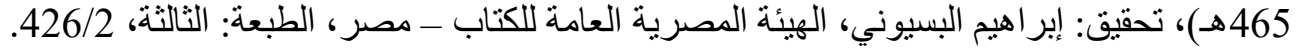

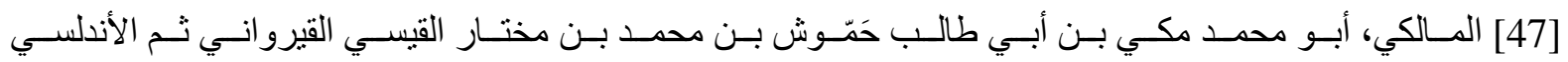

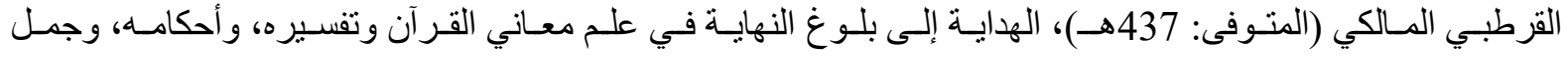

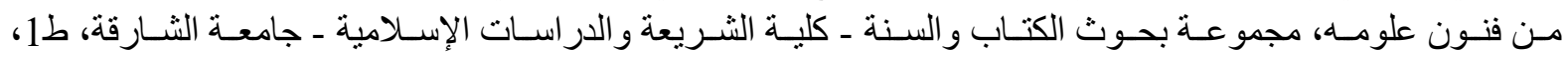

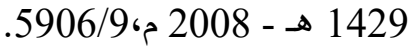

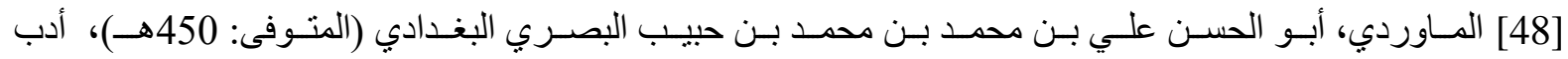

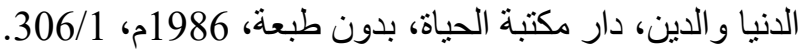

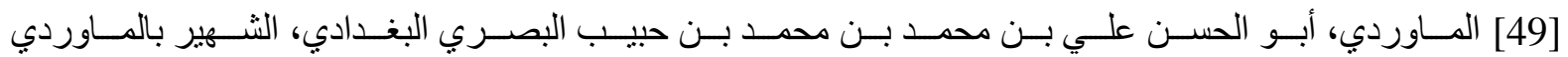

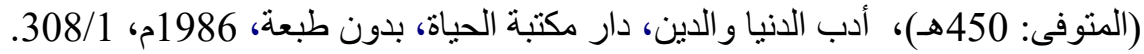

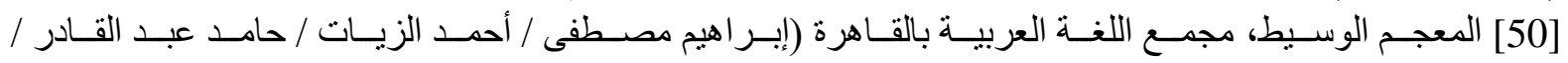
محمد النجار)، دار الدعوة،607/2.

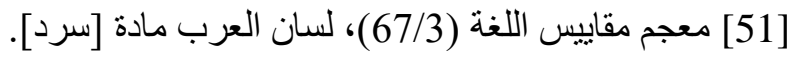

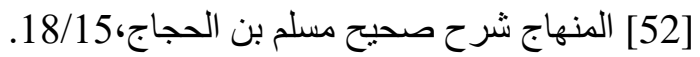

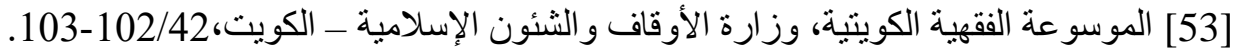

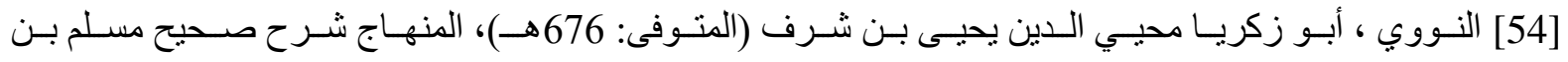

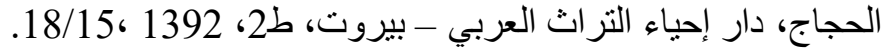

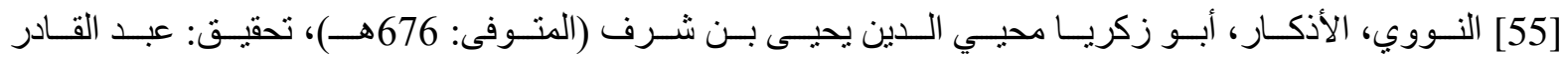

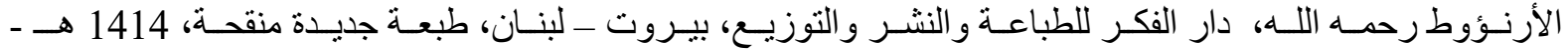

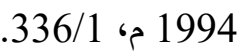

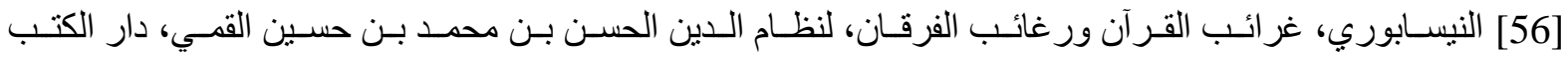

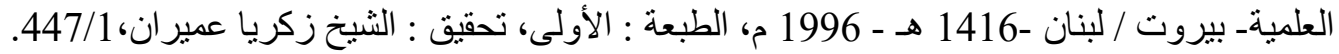




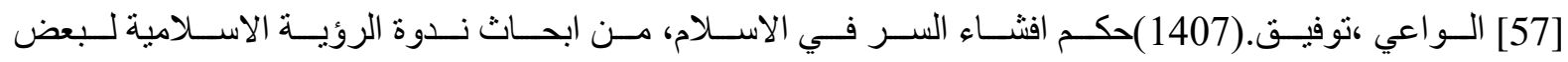

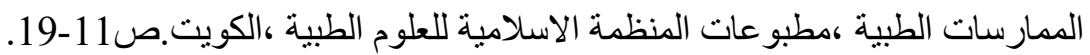

